The final publication is available at Journal of Environment, Development and Sustainability, DOI: 10.1007/s10668-020-00748-4.

Cite this article as: Muñoz-Torres, M. J., Fernández-Izquierdo, M. Á., Rivera-Lirio, J. M., Ferrero-Ferrero, I., \& Escrig-Olmedo, E. (2020), Sustainable supply chain management in a global context: a consistency analysis in the textile industry between environmental management practices at company level and sectoral and global environmental challenges,

Environment, Development and Sustainability, 10.1007/s10668-020-00748-4.

\title{
Sustainable supply chain management in a global context: A consistency analysis in the textile industry between environmental management practices at company level and sectoral and global environmental challenges
}

María Jesús Muñoz-Torres, María Ángeles Fernández-Izquierdo, Juana María RiveraLirio Idoya Ferrero-Ferrero ${ }^{1}$, Elena Escrig-Olmedo munoz@uji.es; afernand@uji.es; jrivera@uji.es; ferrero@uji.es; eescrig@uji.es

Sustainability of Organizations and CSR Management Research Group-IUDESP, Universitat Jaume I, Campus del Riu Sec - Avda. Vicent Sos Baynat s/n, Castellón, 12071, Spain

\begin{abstract}
In a global context, it is crucial to measure and report the corporate sustainability impacts taking into account what is happening along the whole supply chains. The objective of this study is to analyze whether environmental measurement and reporting practices, currently developed by companies under a global supply chain context, are aligned with global environmental challenges and the environmental hotspots at the sectoral level. To tackle this objective, this study has been focused on the textile sector, due to the relevance of its environmental impacts. A research was conducted based on the analysis of global environmental challenges: 1) at company level, on the measurement and reporting of specific environmental indicators connected with the impact categories of the European Organization Environmental Footprint (OEF); and 2) on the analysis of textile industry environmental hotspots, through the technical tool SimaPro that allows their quantification and identification along the life cycle phases using different scenarios. The results show a consistency between global environmental challenges and company environmental disclosure; however, a disconnection between the specific

\footnotetext{
${ }^{1}$ Corresponding Author: Idoya Ferrero-Ferrero, Sustainability of Organizations and CSR Management Research Group - IUDESP, Universitat Jaume I, Castellón de la Plana (12071), Spain, e-mail address: ferrero@uji.es, telephone: +34964387143
} 
environmental indicators reported by textile companies and the main hotspots of the sector are observed. This implies that companies could be managing environmental issues related to global environmental concerns but ignoring those critical environmental issues truly relevant from a technical point of view, according to the nature of their activity. The paper argues that is not only necessary to consider the corporate awareness regarding global environmental challenges, but also to address the real environmental hotspots at the sectoral level. This paper represents a contribution in the discussion about what sustainability management implies along the supply chains, emphasizing the need to advance in a consistent and science-based integration of global environmental challenges, environmental hotspots at the sectoral level and environmental management practices at company level. The results obtained help global chain actors and other organizations to address this challenge.

Keywords: European Organization Environmental Footprint (OEF), global supply chain, sustainability measurement and reporting, textile industry environmental hotspots.

\section{Introduction}

Sustainable supply chain management, especially in global economic environments, has been gaining momentum in the last decades (Koberg and Longoni, 2019). The corporate management of economic, social and environmental impacts without considering the cascade of impacts along the supply chain shows a biased and unrealistic picture of company sustainability. Supply chain management is especially relevant in a context of multinational corporations, with complex and heterogeneous chains of suppliers which frequently operate in developing and lowcost countries; however, research in this topic is still embryonic (Muñoz-Torres et al., 2018a; Tseng et al., 2019).

The significant societal pressures increase on companies to better manage their sustainable supply chain, has been parallel to a proliferation of theories - e.g. organizational theories for Green Supply Chain Management (Sarkis et al, 2011)—, research proposals and measurement, and reporting tools related to the integration of social and environmental issues into global supply chains (Muñoz-Torres et al, 2018a).

During the last decade, proposals for sustainable supply chain management are being based on a life-cycle thinking approach (for instance, Hoogmartens et al., 2014; Halog and Manik, 2011; Souza et al., 2015). As Rajesh (2018) mentions, sustainable supply chain management includes managerial practices for a sustainable production that covers the whole product life cycle. This approach provides an overall view of the impacts derived from products along their life cycle and of the actors involved beyond leading company boundaries and extends the traditional supply chain network (Fandel and Stammen, 2004). Tools for monitoring impacts on sustainability, such as Life Cycle Assessment (LCA) (Arcese et al., 2017; Tsalis, et al., 2017) and footprints methodologies (Cûcêk et al., 2012), have been developed in order to tackle the challenge of integrating sustainability issues into global supply chains (Muñoz-Torres et al., 2018a). However, despite the evidence of interactions between LCA and supply chain management, further interaction should be encouraged and more comprehensive knowledge of its current practical situation should be broadened (Blass and Corbett, 2017). 
In this context, this paper explores whether companies are managing their sustainability impacts, based on life cycle thinking, consistently with the critical economic, social and environmental impacts within a sustainable supply chain context. To that end, the focus is put on companies measurement and reporting practices as a measure of this sustainability management.

As Maas et al. (2016) highlight, 'for effective improvement of sustainability performance (...), both measurement and management for internal performance improvement and external transparency purposes need to be linked (...)'. Companies communicate their sustainability results in two directions: internally, for managers to assess economic, environmental, social and governance risks; and externally, for parties outside the organization to make informed decisions based on relevant data. In fact, as Adams and Frost (2008) show, processes of reporting data externally has had positive impact in the integration of corporate sustainability performance data into decision-making processes or risk management, among others. These interactions allow to view sustainability reporting practices as a proxy for the analysis of company's sustainability management system (Moneva et al., 2007).

Specifically, this research focuses on environmental sustainability to examine the key issues that should define measurement and reporting practices in order to advance in sustainable development. In this sense, an environmental measurement and reporting practice can consistently contribute to sustainable development if: i) it is consistent with global environmental challenges; and ii) it is consistent with industry environmental hotspots. The objective of this study is to analyze whether environmental measurement and reporting practices currently promoted by companies under a supply chain context are aligned with global environmental challenges and sectoral hotspots.

This study has been developed in the textile sector due to the relevance of its environmental impacts and the complexity of its global supply chains. The textile sector is one of the largest industries in the world with high environmental and social impacts on the different product life cycle phases —raw material acquisition, fabric production, garment manufacturing, transport, use and reuse/end of life_- (Liu et al., 2017; Parisi et al., 2015; Zamani et al. 2015). The scope of this paper is limited to the environmental dimension, as it is the most studied dimension in sustainability measures and reporting practices (see Seuring, 2013).

From these, the following research questions can be stated:

RQ1: Are companies which belong to different textile life-cycle phases, measuring and reporting relevant environmental issues for supply chain management, in accordance with global environmental challenges?

RQ2: Are companies which belong to different textile life-cycle phases, measuring and reporting relevant environmental issues for supply chain management, in accordance with textile industry environmental hotspots?

In order to answer these questions, an analytical research was designed based on the environmental impact categories considered by the European Organization Environmental Footprint (OEF). OEF is a tool which integrates a life cycle approach and defines a comprehensive range of environmental impact categories that could be directly related not only with the most significant global environmental challenges, but also with every potential environmental hotspot that a company could manifest (European Commission, 2013). 
Global environmental challenges have been identified according to policy and societal issues defined by Sustainable Development Goals and COP21. As regards to textile industry environmental hotspots, sectoral literature review, expert knowledge and the technical tool SimaPro have been the references used for their quantification and identification of a cotton tshirt producer company, as sectoral representative product.

The aforementioned research questions lead to the reflection about the consistency between the environmental topics that companies could deal with inspired or pressured by their institutional context (as proposed by Gunarathne and Lee, 2019), and the real environmental hotspots that should be managed by the company according to industry technical data.

The remaining part of the paper proceeds as follows. Section 2 covers the literature review on supply chain environmental management in textile global contexts. Section 3 is focused on the description of the European Organization Environmental Footprint as the frame of reference for this paper. Section 4 includes the research design. Section 5 shows the main results obtained, Section 6 focuses on the discussion of these results and the final section highlights the main conclusions of this research.

\section{Supply chain environmental management in global contexts for the textile industry.}

This section analyses supply chain environmental management in textile industry, and presents a literature review regarding supply chain sustainability in general and textile supply chains in particular, including current key questions across environmental impacts management along the textile supply chain.

\subsection{Supply chain sustainability}

The integration of environmental, social and economic criteria in supply chain management is a key issue of sustainable development (Taticchi et al., 2013; Diabat et al., 2014). As Sarkis (2019) remarks, 'focusing on organizations alone and separately may provide only some, fractional, opportunities for improving environmental and economic sustainability. The greatest influences and opportunities occur across and between organizations. Thus, the supply chain is critical for a more complete, systemic and holistic perspective of sustainability concerns caused by commerce and industry'.

However, the mere consideration of sustainability concerns by companies along the supply chain does not guarantee a positive impact on sustainability. Notwithstanding the increase of organizational commitments towards sustainable development, Barbosa-Póvoa et al. (2018) highlight the failure of most companies to implement tangible measures for an effective management of supply chain sustainability. The authors mention the need to understand what is important at the corporate level for supply chain sustainability as one of the key questions for addressing this limitation. In this sense, global sustainability challenges cannot be tackled without the active involvement of companies but, in addition, companies cannot avoid those sustainability impacts that are technically relevant considering their activity. Consequently, the identification process of relevant sustainability issues for companies in a supply chain context should cover not only global sustainability challenges but also specific sustainability issues relevant for the company from a technical point of view. 
Other important question identified by the literature around supply chain sustainability is the bias of studies towards the production function (Brandenburg et al., 2014), with less attention to the study of supply chain management based on the upstream and downstream supply chain (Tseng et al., 2019).

Therefore, despite the consideration of sustainability concerns into organizational practices is gaining momentum in research around supply chain management (Martins and Pato, 2019), the analysis of sustainability impacts on whole global supply chains, considering those impacts relevant both from a global and industry-specific perspectives, require further attention at academic and a practical level.

\subsection{Textile supply chains}

The textile industry is one of the most global industries in the world (Muñoz-Torres et al., 2018b). A clear necessity to integrate sustainable management in its supply chain is recognized (Desore and Narula, 2018).

A common issue in many papers (e.g. Roos et al., 2016; Zamani et al., 2017; Testa et al. 2017; Uluskan and Godfrey, 2018; Zimon and Domingues, 2018) is the broad complexity of the textile supply chain. This complexity arises from different reasons. First, the textile supply chain is characterized by a large number of suppliers (Liu et al., 2017) with a widespread adoption of outsourcing in developing countries to minimize labor and production costs. These countries present a large degree of political, legal and economic uncertainty and problems related to high corruption rates (Köksal et al., 2017), human rights, labor exploitation and environmental pollution (Uluskan and Godfrey, 2018). Second, customers are supposed to have decisive bargaining power; however, the importance of social and environmental concerns is downplayed in the end consumer decision making process as the production processes are carried out by a dispersed supplier map located far away from sales markets (Zimon and Domingues, 2018) and the quality and quantity of relevant information is scarce and outdated (Van der Velden et al., 2014). Third, most textile products undergo sea changes in trends and styles and have a very short flow time in the product life cycle in which at least four or five subcontractors for each process outsourced may be involved. In addition, the product impacts during user or end of life phases have a high dependence on consumer behavior (Testa et al. 2017). These particularities make data collection and impact assessment difficult and flexible and dynamic frameworks to calculate the impacts of textile products are required.

Regarding textile supply chain studies, a significant proportion of articles are focused on the supply chain actors which could be classified into B2B actors (producers of fibers, spinners, weavers, chemical processors, knitters, apparel manufacturers), B2C actors (brand owners, retailers, retail shops) and customers (Parisi et al., 2015; Kumar et al, 2017). With regard to life cycle thinking, the articles usually define the following phases: i) raw materials; ii) yarn production; iii) fabric production; iv) garment manufacturing; v) transportation and distribution; vi) consumer use; and vii) disposal and recycle (Muñoz-Torres et al., 2018b; Lambooy et al., 2017; Zamani et al., 2015; Zhang et al., 2018). Given the global nature of textile life cycles, particular attention should be paid to the physical location of phases, and take into account the regional patterns of production and consumption and the transportation impacts (Roos et al., 2016). For instance, China is one of the most relevant cotton producers (Piontek and Müller, 2018), Turkey and Vietnam are important regions in the production phase (Baydar et al., 2015; 
Lambooy et al., 2017) and The United States is the largest importer of textile products in the world (Seyoum, 2010). Regarding the consumer use phase, studies (e.g. Piontek and Müller, 2018; Zhang et al. 2018) deal with the difficulty to estimate the environmental impacts, since the results depend on consumer behavior such as washing, drying and ironing times per garment and washing temperature. Concerning the disposal and recycle phase, more articles are clearly needed to assess the benefits of using textile waste as a resource for feed production or consumer processes within a circular economy framework. Some of the few ones addressing this include a literature review on life cycle assessment in the textile industry (Piontek and Müller, 2018), and even less studies focusing on the reuse, the second-hand or the renting options (e.g. Ferrant et al., 2010; Muthu et al., 2012) or the recovering of raw materials (Esteve-Turrilla and De la Guardia, 2017).

\subsection{Environmental impacts management in textile sector}

The textile industry has been severely criticized for different reasons: i) generating a dramatic social and environmental impact due to the use of harmful chemicals for humans and the environment; ii) the consumption of large amounts of energy from non-renewable resources; iii) the high consumption of water, often producing harmful effluents; iv) the generation of large quantities of wastes, difficult to manage as a new resource or recycle; v) the huge fuel consumption for transportation due to remote places where textile fabrics are located far away from end consumers; vi) the use of non-biodegradable packaging materials or substandard labor conditions (Choudhury, 2014; Hasanbeigi and Price, 2015; Zamani et al. 2015; León et al. 2016; Liu et al., 2017; Parisi et al., 2015), among others.

This study is focused on the most examined sustainability dimension, i.e. the environmental dimension. As Seuring (2013) literature review of more than 300 paper states, the environmental dimension dominates, in comparison with social and economic aspects.

In relation to textile environmental impacts, technical studies (Bevilacqua et al., 2014; Erdil and Tazgin, 2018; Rana et al., 2015; Steinberger et al. 2009; Zhang et al., 2018) are difficult to compare since results diverge depending on the data used, the impact categories considered, the technology applied in the garment production and the assumptions made (Piontek and Müller, 2018). Nonetheless, on the basis of common findings, this study highlights the textile industry environmental hotspots. A hotspot could be defined as a life-cycle phase, process or elementary flow which accounts for a significant proportion of the impact of the functional unit (UNEPSETAC, 2017).

Environmental impacts are generated at the different phases of the textile product life cycle (Zamani et al., 2017) and are also affected by geographical operations allocation (Roos et al., 2016).In the raw material phase, in particular, in cotton production, literature identifies the use of pesticides, herbicides and artificial fertilizers as hotspots, which involves a large amount of residual toxic and harmful substance in the soil and in the groundwater; as well as the use of water which leads to water resource depletion (Bevilacqua et al., 2014; Rana et al., 2015). In the textile production phases, authors such as Zhang et al. (2018) state that the printing and dyeing processes are those that have larger environmental impacts. The printing and dyeing processes require a huge amount of energy, chemicals and water (Bevilacqua et al., 2014, Zhang et al., 2018). Energy consumption is necessary for steam, power of motors, direct heat for drying, air compressors, air conditioning, and cooling; chemicals in dyes and garment manufacturing are 
included to obtain the specific functions of the textile, such as color, resistance or water repellency; and water is used as a solvent for dyes and chemicals and as a medium for transferring dyes and chemicals to fabric, mixing the untreated wastewater into streams and rivers. The consumer use phase has a significant environmental impact due to energy and water consumption of washing, laundering and ironing processes as well as customer transport (Piontek and Müller, 2018; Rana et al., 2015). Studies, such as Steinberger et al. (2009), show that the highest energy use and $\mathrm{CO}_{2}$ emissions occur in the consumer phase when a t-shirt is used. The recovery phase has been less studied (Dahlbo et al., 2017) but the research from Esteve-Turrillas and De la Guardia (2017) shows that the use of recover cotton selected from textile wastes overcomes the impact of cultivation and dyeing phases, with the only increasing impact on energy consumption.

In this context, the textile industry faces pressures for minimizing its negative impacts on the environment (Xu et al., 2013; Wu et al., 2012). In this respect, institutional theory (Meyer and Rowan, 1977) states that the organization behavior is affected by rules, norms, values, expectations and influence of institutional members. Consequently, the institutional pressure such as government regulations, stakeholder's environmental consciousness, or the international political agenda, push organizations to adopt proactive environmental strategies, which are extended along supply chain (Wu et al., 2012). Empirical studies have explored the institutional pressure on green supply chain management in the textile industry (Diabat et al., 2014; Wu et al., 2012; Xu et al., 2013) which is one of the polluting sectors (Desore and Narula, 2018). In this respect, $\mathrm{Xu}$ et al. (2013) find evidence that the international standards pressure textile industry in India to adopt green supply chain management with the aim of facilitating its exports. Similarly, Wu et al., (2012) consider three institutional pressures, market, regulatory and competitive pressures, as moderating factors between drivers and environmental management practices along supply chains, although their empirical research only find as a significant factor the regulatory pressure. Likewise, Diabat et al., (2014) also identify similar influential enablers for integrating sustainability in the management of supply chain in Indian textile industries. However, they find that government regulations present a weak influence on sustainability implementation in supply chains and they suggest more strict regulations on textile industry to adopt environmental practices.

These results require further attention about the issues included in the institutional pressures, not only at national level but also in a global context, especially for industries that operate globally, and considering the presence of supranational initiatives which try to address the environmental challenges. The global environmental challenges shape global development policies and contribute to companies to be at the forefront of innovative practices and to meet the stakeholder's expectations (Dauvergne and Alger, 2018). In this vein, a global supply chain, like textile one, should address the global environmental challenges. However, there is a gap in the empirical research concerning the consistency between those global environmental challenges and the management practices (measuring and reporting) at companies' level along the whole textile supply chain. This study addresses this research gap in the first research question.

RQ1: Are companies which belong to different textile life-cycle phases, measuring and reporting relevant environmental issues for supply chain management, in accordance with global environmental challenges? 
A second question that remains unclear refers to the relationship between the environmental management practices and the real impacts of the companies' operations along the supply chains. There are not commonly accepted frameworks that make it possible to measure and report the sustainability performance of the supply chain to support decision-making (Cohen et al., 2012; Muñoz et al., 2018a; Schalteger and Burrit, 2014; Tasdemir et al, 2019). In the absence of these accepted metrics, companies may use sustainability management tools to hide their actual operations and manipulate stakeholder's perceptions about the real impacts of their activities. Moreover, the competing assessment methods are based on simple concept such as energy efficiency that could not give a whole picture of the real impact in a comprehensive way (Garrido Azevedo et al., 2017). In fact, the limited knowledge about sustainability impacts does not allow to perform a comparison based on the real impacts of companies and their products, to make the right decision to choose the more environmentally friendly option (Desore and Narula, 2018) or to address the hotpots of the industry. In this regard, further research is needed to show whether or not companies are managing key industry-specific hotspots. To obtain insight into this gap, the second research question digs on the relationship between the environmental management practices at company level and what is critical for textile industry from the environmental perspective.

RQ2: Are companies which belong to different textile life-cycle phases, measuring and reporting relevant environmental issues for supply chain management, in accordance with textile industry environmental hotspots?

\section{Organization Environmental Footprint: a reference frame for the identification and management of textile environmental hotspots along global supply chains}

There is no consensus about how the sustainability performance of supply chains can be measured (Garrido Acevedo et al, 2017, Rajesh, 2019). Focusing on the tools and methodologies to measure and account for the environmental impacts on the supply chain, the vast majority of articles base their empirical analysis on life-cycle assessment (e.g. Bevilacqua et al., 2014; Rana et al., 2015, Esteve-Turrillas and De la Guardia, 2017; Zhang et al., 2018). In these cases, the articles define a particular product as a functional unit of the assessment (e.g. 2 tons of polyestercotton product; $1 \mathrm{~kg}$. of dyed cotton yarn) and usually apply a life cycle assessment to compare different scenarios such as conventional technology vs. best available techniques or materials (e.g. Nieminen et al., 2007; Van der Velden, 2014; Esteve-Turrillas and De la Guardia, 2017; Zhang et al., 2018) or regarding companies' location (e.g. Bevilacqua et al., 2014; Liu et al., 2017). Nonetheless, a greater standardization of methods applied in the life cycle assessment regarding the impact categories should be achieved and a common assumption with the aim of improving the comparison of results between studies should be made (Piontek and Müller, 2018). In this respect, Testa et al. (2017) adopted a life-cycle assessment based on the Product Environmental Footprint (PEF) methodology issued by the European Commission (2013), which aims to provide a robust methodology for computing environmental impacts in order to avoid greenwashing. In this study, Testa et al., (2017) highlighted the importance of collaboration, i.e. putting common efforts and sharing resources among different actors in a specific sector, like SMEs of an industrial cluster and the Chamber of Commerce, so as to support the adoption of life cycle assessment, in particular the PEF, through a common understanding of sustainability challenges. Bamonti et al., (2016) used the PEF to identify the environmental performance of recycled wool. Other studies focused on one of the impact 
categories, e.g. carbon footprint (e.g. Zamani et al., 2015) or carbon and water footprint (Liu et al., 2017).

Despite the capacity of Environmental Footprint as a management and communication tool in global supply chain and the possibility of applying this footprint in organizations such as the Organization Environmental Footprint (OEF) (European Commission, 2013), there is a limited number of studies that use the Environmental Footprint as a relevant information tool to manage, compare or assess environmental corporate performance (e.g. Pelletier et al., 2014). In this respect, this study uses the OEF as a reference since it is one of the most robust methodology for assessing the environmental impacts in terms of life cycle thinking (Testa et al., 2017).

The Environmental Footprint of Organizations (OEF) has been defined by the European Commission in the document "Commission Recommendation of 9 April 2013 on the use of common methods to measure and communicate the life-cycle environmental performance of products and organisations", especially in its annex III "Organization environmental footprint guide". The OEF is focused on the measurement of environmental impacts at the organizational level, which provides a holistic outlook on the traditional use of LCA of products over its entire life cycle (Neppach et al., 2017). Thus, the European Commission is devising the OEF method based on life-cycle oriented methods, with the aim of identifying environmental hotspots, benchmarking, business-to-business (B2B) relationship and, mainly, of developing a common methodology for measuring an organization's environmental performance beyond organizational boundaries (Scope 1: Direct emissions, Scope 2: Energy Indirect emissions and Scope 3: Other indirect emissions). It implies to account for the environmental impacts that could occur in downstream and upstream processes along the supply chain.

The common method for measuring the organization environmental performance encompasses the definition of specific categories of environmental impacts at the organizational level which include resource use or emissions of environmentally damaging substances that may affect human health. Concretely, the fourteen environmental footprint impact categories for OEF studies are (European Commission, 2013): Climate Change, Ozone Depletion, Ecotoxicity, Fresh Water, Human Toxicity-Cancer Effects, Human Toxicity-Non-Cancer Effects, Particulate Matter/Respiratory Inorganics, Ionizing Radiation, Human Health Effects, Photochemical Ozone Formation, Acidification, Eutrophication-Terrestrial, Eutrophication-Aquatic, Resource Depletion-Water, Resource Depletion-Mineral, Fossil and Land Use.

The OEF is consistent with the ecological system defined by the main international references which provide frameworks for the institutional addressing of global environmental challenges, i.e., COP21, SDGs or Planetary Boundaries. On the one hand, the OEF impact categories are directly associated to the main topic of the United Nations Framework Convention on Climate Change (UNFCCC). At the 21st conference of the UNFCCC in Paris in December 2015, the Parties adopted the so-called Paris Agreement, or COP21, in order to deal with the global temperature increase, especially related to greenhouse gases emissions. The OEF impact category "Climate Change" is a clear evidence of the OEF-COP21 relationship.

Table 1 presents the close relationship between the fourteen impact categories of the OEF with the nine issues which define the so-called Planetary Boundaries, i.e., the quantification, for each key 'Earth System processes', of 'the boundary level that should not be transgressed if we are to avoid unacceptable global environmental change' (Rockström et al., 2009). Table 1 also illustrates the SDGs concerns related to the environmental footprint impact assessment issues 
included in the OEF. In particular, the OEF can be associated with the Sustainable Development Goals number 3. Good Health and Well-Being; 6. Clean Water and Sanitation; 7. Affordable and Clean Energy; 11. Sustainable Cities and Communities; 12. Responsible Consumption and Production; 13. Climate Action; 14. Life below Water; and 15. Life on Land.

\{Insert Table 1. Relationship between OEF impact categories, Planetary Boundaries and SDGs Here\}

The European Commission OEF is at a development stage. Due to its complexity, the tool is being tested in several pilot cases in order to offer a more comprehensive definition of Organizational Environmental Footprint Sector Rules, which could deal with the specifications of certain sector requirements. Despite this, the OEF is currently considered to be a robust method for corporate environmental performance measurement and reporting (Pelletier et al., 2014). For this reason, in this research the OEF is considered as a frame of reference for the identification and management of textile environmental hotspots along global supply chains.

\section{Research design}

Research design involves the following steps:

\{Insert Figure 1. Flow chart of the study Here $\}$

According to the information analyzed from different sources (academic literature and sectoral guidelines and standards), a generic structure of a textile product life cycle has been determined.

A textile product can be defined as 'any raw, semi-worked, worked, semi-manufactured, manufactured, semi-made-up or made-up product which is exclusively composed of textile fibres, regardless of the mixing or assembly process employed' (European Union, 2011).

Based on Muñoz-Torres et al. (2018b), Figure 2 shows the nine phases of the textile product life cycle.

\section{\{Insert Figure 2. Textile product life cycle Here}

Bearing this textile product life cycle in mind, the paper has been divided into two main parts to respond to the research questions.

\subsection{Analysis of environmental aspects measured and reported by textile companies}

In order to show the consistency between the environmental aspects that companies could be measuring and reporting inspired or pressured by their institutional context, the level of disclosure of specific indicators connected with the impact categories of the European Organization Environmental Footprint (OEF) in textile sector has been analyzed. To that end, the methodology used has been structured as follows:

Step 1: Considering the defined textile product life cycle, the most relevant companies in terms of sustainability in each life cycle phase have been selected based on the following criteria: 
- Identification of the activity code (NACE code) of the companies in each life cycle phase;

- Identification of the best companies which belong to each activity code according to their sustainability score provided by Thomson Reuters ASSET4 database. Note that "best companies" means those companies with the highest sustainability score which is based on the self-reported information in the environmental, social and corporate governance dimensions;

- Consideration of additional sources, like suppliers lists published by large companies, with the aim of validating the suitability of the selection; and

- Application of a snowball methodology to extend the sample to other relevant companies in terms of sustainability not included in Thomson Reuters ASSET4 database.

Figure 3 presents the economic activities (NACE codes) associated with the textile product life cycle and the number of companies analyzed by each life cycle phase. The total number of companies explored in this research has been $31^{2}$. This set of companies is heterogeneous in terms of size, legal form and geographical location.

\{Insert Figure 3. Number of organizations and economic activities analyzed by the textile product life cycle Here\}

Step 2: Analysis of public information on environmental performance indicators and practices of the companies selected in the previous step (Sustainability reports, Integrated reports, Websites, etc.). The data were collected in April, May and June 2018.

Step 3: Review of reference sectoral guidelines, standards and certifications used by companies for the management of environmental concerns at each life-cycle phase.

Step 4: Categorization of the information according to the environmental impact categories defined in the European Organization Environmental Footprint (OEF). Concretely, the level of disclosure of specific indicators has been connected with the impact categories of the OEF. Although the quality of environmental disclose is relevant for sustainability purposes (see Helfaya and Whittington, 2019 or Lee, 2017, among others), the scope of the research in this phase is focused on a gap identification, determining if the company is measuring their environmental performance according to a selected list of impact categories or not (presence/absence).

\subsection{Analysis of sectoral hotspots}

Textile industry environmental hotspots have been identified through the technical tool SimaPro and a working group of experts following the methodology of UNEP-SETAC (2017) hotspots analysis. This method allows users to perform different actions connected with hotspots inquiry. To that end, the research design has been structured as follows:

Step 1. Definition of three analysis scenarios adapted to a cotton-made $t$-shirt life cycle, goal and scope: The objective of this analysis is to consider the most relevant environmental impacts

\footnotetext{
${ }^{2}$ List of companies are listed in Muñoz-Torres et al. (2018b) and details are available upon request.
} 
identified in the OEF and the crucial hotspots for the textile sector. Therefore, the previous textile product life cycle has been adapted to a cotton-made t-shirt life cycle.

\section{\{Insert Figure 4. Cotton-made t-shirt life cycle Here $\}$}

Figure 4 displays the nine phases (as presented in the literature review) of a cotton-made t-shirt life cycle. The main phases are:

- Raw material acquisition. The first phase includes cotton growing, harvesting and ginning;

- Fabric production. The second phase comprises carding, spinning, dyeing, washing and rising;

- Garment manufacturing. This phase refers to cutting, sewing, washing and embroidering;

- Consumer Use. The fourth phase shows the consumer buying the t-shirt, wearing and washing it and finally discarding the t-shirt or donating it for second life;

- End of life. This phase includes the disposal to dumpsites; and

- Transportation throughout the life cycle was also included.

To answer the research questions a cotton-made $t$-shirt has been chosen to be the unit of analysis as, according to Beton et al. (2014), it is one of the best-selling items of clothing in Europe.

Considering the previous cotton-made t-shirt life cycle and the companies integrated in this life cycle, three scenarios have been defined to analyze the main textile industry environmental hotspots. The functional unit chosen for this research is 1 cotton-made t-shirt, as reported in other studies on textile processes (among others: Choudhury, 2014; Van der Velden et al., 2014; Zamani et al., 2015; Roos et al., 2016). Table 2-4 summarizes the most relevant inputs for these three scenarios.

Scenario 1: The cotton for the t-shirt stems from the USA (15.6\%), China (29.8\%) and the rest of the world, mainly India and Pakistan, (54.6\%) (based on data regarding cotton production around the world for 2014/2015 published by the US Department of Agriculture). In this specific case, the cotton-made t-shirt is knitted, cut, sewn, embroidered and washed in companies in China. After the production of the fabric, the cotton is shipped to a manufacturing facility site in Turkey. The cotton-made t-shirt is sold in shops in Europe. The product is washed and dried for 50 cycles during the period of use. In the end-of-life phase, t-shirt is thrown away to a landfill (treatment of municipal solid waste) and no recycling is considered.

\{Insert Table 2. Life-cycle phases of the cotton t-shirt without reuse Here $\}$

Scenario 2: This scenario differs from the first scenario in the reuse phase, because in this scenario, the cotton-made t-shirt is reused as a second-hand item of clothing. Concretely, in this scenario, the use phase is divided into two stages. First, there is a phase of use in a developed country (Germany) where the t-shirt is washed and dried for 40 cycles during the period of use. After that, there is a reuse phase in a developing country (in this case, Ivory Coast) where is hand-washed for 25 cycles, thus extending the phase of use of the product. At the end-of-life phase, the t-shirt is treated as municipal solid waste (incinerated).

\{Insert Table 3. Life-cycle phases of the cotton t-shirt with reuse Here 
Scenario 3: In this scenario, a local market has been defined. All companies and users from the life-cycle phases of the cotton-made t-shirt were in the USA.

\{Insert Table 4. Life-cycle phases of the cotton t-shirt in the USA Here $\}$

Step 2. Three testing scenarios (gather data, seek expert advice): The defined scenarios have been tested. Therefore, the SimaPro tool has been used as a source of quantitative data. This LCA database has been widely used in the literature to evaluate the main environmental impacts of the textile industry (e.g. Parisi et al., 2015). In particular, we have looked at the data provided by Ecoinvent V3.2, our primary source of information. Ecoinvent offers life-cycle inventory (LCI) and life-cycle impact assessment (LCIA) results. Life-cycle impacts were assessed based on ILCD 2011 Midpoint+ V1.10/ECJRC Global, equal weighting. Table 5 shows the environmental impact categories included in this study. These impact categories are linked with the impact categories defined in the Organizational Environmental Footprint.

\{Insert Table 5. Environmental Impact Categories and units Here $\}$

Step 3. Identification and validation of textile hotspots: After gaining the technical information from the SimaPro analysis, the H2020 WP5 SMART Project team, which comprises 10 researchers, have held regular formal and informal meetings to define the scope of each impact on the different phases of the life cycle and reach a consensus on the OEF impacts that can be considered as critical points for the different companies that collaborate throughout the $\mathrm{t}$-shirt life cycle.

Given the diversity of measurement units shown in Table 5, a ponderation system using micropoints has been implemented according to ILCD 2011 Midpoint+ V1.10/ECJRC Global, equal weighting, with the aim of comparing results among scenarios. The higher the value, the more significant the environmental impact.

The criteria applied for identifying the sectoral hotspots follows UNEP-SETAC (2017) and Guidance for the implementation of the EU PEF during the Environmental Footprint pilot phase (European Commission, 2016), where hotspots are elementary flows 'cumulatively contributing at least 50\% to any impact category' before normalization and weighting.

\section{Results}

This section presents, firstly, the environmental topics measured and reported by companies belonging to the textile product life cycle; secondly, the sectoral hotspots obtained from a technical point of view, and finally, the comparative analysis of these results in order to answer the research questions. 


\subsection{Environmental topics managed and reported by textile companies}

Table 6 presents the level of measurement and reporting of the specific indicators connected with the impact categories of the environmental footprint (OEF), where the rows show impact categories and columns list the textile products life-cycle phases.

\{Insert Table 6. Environmental Footprint impact category and company indicators Here\}

The environmental dimension presents an unbalanced level of development in terms of lifecycle phases and environmental impact categories. In spite of the general absence of environmental information, the "climate change" and "mineral fossil and resource depletion" categories (resource efficiency) are exceptions since they are widely addressed along the eight phases of the textile product life cycle.

The most common indicator is "Total $\mathrm{CO}_{2}$ emissions in tons" which is directly associated with climate change. This indicator is also calculated under the concept of scopes (Scope 1 - Direct emissions, Scope 2 - Energy Indirect emissions and Scope 3 - Other indirect emissions) mainly by those companies which are at the manufacturing and transportation and distribution phases. In the case of the 'Disposal/Reuse' phase, a common indicator is the generation of renewable energy which is expected given the type of activities that companies perform at this phase. Focusing on the resource depletion categories, related indicators typically used are "water consumption" and "total weight of waste (hazardous and non-hazardous waste)". It is important to highlight that these indicators are partially associated with a specific impact category; however, they are not enough to measure the corporate performance of the whole impact category.

With respect to life-cycle phases, an important finding is that, at the initial phase, a large number of indicators come from companies that manufacture fibers; companies that produce plant-based fibers (e.g. cotton) or animal fibers provide a very limited number of sustainability indicators. Regarding "consumer use", anecdotal information has been found and the indicators provided were "percentage of water reused" and "percentage of recycled material rate per product purchased".

\subsection{Sectoral hotspots}

Regarding the textile industry environmental hotspots, Table 7 presents the results of the 14 OEF impact categories that arise from each scenario.

\{Insert Table 7. Impact analysis results by scenarios Here $\}$

With the aim of identifying the most relevant impact categories, Figure 5 shows the weighted results. Analyzing the results in overall terms, four impact categories could be identified as the most important ones for the textile sector: i) "water resource depletion", ii) "human toxicitycancer effects", iii) "freshwater ecotoxicity" and iv) "human toxicity-non-cancer effects".

\{Insert Figure 5. Textile industry environmental impact categories by scenarios Here $\}$

The three scenarios show robust results since they do not reflect substantial changes in terms of the most relevant impacts identified in each scenario. Nonetheless, differences between 
scenarios 1-2 vs scenario 3 are observed in two categories: "water resource depletion" and "ionizing radiation". In the case of the category "water resource depletion" its impact is lower for scenario 3 compared to scenario 1-2. Concretely, the water depletion indicator (see Table 7), expressed as cubic meters of water required for dyeing 1 cotton-made t-shirt is: $0.65 \mathrm{~m} 3$ (in scenario 1), $0.66 \mathrm{~m} 3$ (in scenario 1), and $0.39 \mathrm{~m} 3$ (in scenario 3). The discrepancies among scenarios in this category can be explained due to the various agricultural techniques employed in cotton farming.

Regarding the category "ionizing radiation", the degree of impact for scenario 3 is higher comparing to scenario 1-2. A possible explanation for this situation could be the presence of different electrical mixes and systems of generation of the electrical energy in each scenario. Electricity in the USA has a greater component of nuclear energy while electric power in China, and especially in the agricultural areas, comes mainly from hydraulic energy.

Table 8 shows the cumulative impact contribution of each life-cycle phase to the overall impact by impact category. In this table, the impact categories have been ordered from the highest to the lowest level of significance of their impact. The results presented in the table have been calculated based on "Scenario 2", since it shows the most complete reference including an underdeveloped country for the end life of the product.

\{Insert Table 8. Cumulative impact contribution of each life cycle phase Here

In order to perform an in-depth analysis of the results by the life-cycle phases, Table 8 reflects that $50 \%$ of cumulative impact contribution to any impact category is reached in the two first phases of the product life cycle. The high percentage achieved in the first phase "raw material acquisition" in the cases of "water resource depletion" (95.5\%), "land use" (92.0\%) and "Ecotoxicity-fresh water" (82.2\%) impact categories is strongly evident.

Concerning the most relevant impact categories, the sectoral hotspot according to UNEPSETAC (2017) has been explored. With respect to the "water resource depletion" impact category, a significant proportion of its impact is due to the irrigation process in cotton farming (raw material phase). The "human toxicity - cancer effects" impact category, the main factor is the anthraquinone compound used in the dying process (fabric production phase); although around $25 \%$ of the impact contribution occurs in cotton farming given the use of pesticides, herbicides and artificial fertilizers. In addition, these products originate a substantial amount of residual toxic and harmful substances in the raw material acquisition phase, which explains the greater impact contribution of this phase to the "Ecotoxicity - fresh water" impact category. As regards the "Human toxicity - non- cancer effects" impact category, 50\% of cumulative impact contribution is reached in the fabric production phase, although an important origin of this impact is due to processes related to the use of certain types of electric energy.

\subsection{Comparative analysis}

With the aim of answering the two research questions, this section presents a comparative analysis between the environmental topics managed and reported by companies, sectoral hotspots and global environmental challenges:

RQ1: Are companies, which belong to different textile life-cycle phases, measuring and reporting relevant environmental issues in accordance with global environmental challenges? 
This study shows that those topics, mainly covered in textile company measurement and reporting systems, are aligned with most of the global environmental challenges which are internationally accepted.

Table 6 shows that companies eagerly seek to measure and report aspects related to climate change. This is consistent with the importance given to climate-change related issues by the different international initiatives (see Table 1): i) SDG 7. Affordable and clean energy; 11. Sustainable cities and communities; 12. Responsible consumption and production and 13. Climate action; and ii) Planetary Boundaries climate change; ocean acidification; nitrogen and phosphorus inputs to the biosphere and oceans and Biodiversity loss. In addition, climate change is specifically addressed by initiatives like COP-21 and is subjected to close scrutiny from governments and the media.

Other indicators, often developed by companies reporting structures, are focused on resource efficiency, which is related to the "Mineral fossil and resource depletion" impact category. This is supported by SDG 15 Life on Land and by Planetary Boundary chemical pollution. In addition, the inclusion of these indicators could be motivated by eco efficiency reasons, which could also be aligned with other initiatives like Circular Economy.

Water and land use concerns are also highlighted as global environmental challenges and global risks (see Table 1). In this respect, these topics have a certain relevance for companies in their measurement and reporting systems (see Table 6).

RQ2: Are companies, which belong to the different textile life-cycle phases, measuring and reporting relevant environmental issues in accordance with textile industry environmental hotspots?

The empirical evidence shows that companies which belong to the different textile life-cycle phases are not measuring and reporting enough relevant environmental issues according to sectoral environmental hotspots in order to provide a clear and reliable picture of the total sectoral environmental impacts.

Table 9 shows the combination of the results from the sectoral hotspots and the environmental aspects managed and reported by the companies analyzed. Note that figures present the degree of impact contribution of each life-cycle phase to the overall impact category.

\{ Insert Table 9. Relationship between environmental hotspot and environmental aspects managed and reported by companies Here \}

Two of the main hotspots are associated to "Water resource depletion" and "Ecotoxicity-fresh water" impact categories and take place in the first phase "raw material acquisition". In this regard, it can be observed that companies at this phase provided limited information for both impact categories. Other hotspots take place in the phase "fabric production" and are related to "Human toxicity- cancer effects" and "Human toxicity- non-cancer effects" impact categories. In this case, a total lack of information regarding these issues was observed. This situation is also common in the rest of the impact categories, with the exception of "Terrestrial eutrophication". This lack of information is plainly evident in the second phase "fabric production" where the greatest degree of environmental impact of textile products regarding the overall life cycle was found. 
Consequently, the results show a consistency between global environmental challenges and company environmental disclosure; however, a disconnection between the specific environmental indicators reported by textile companies and the main hotspots of the sector are observed.

\section{Discussion}

In the last years, a special effort by relevant international institutions and research networks has been made in other to face global environmental risks such as COP-21, SDGs and Planetary Boundaries, among others. These initiatives have a positive impact in terms of societal awareness regarding the need to tackle environmental issues such as climate change, water use or ozone depletion. However, in a business context, there is a risk of bias in the environmental efforts to address these issues at the expense of other relevant environmental impacts, especially considering the sectoral particularities. This study analyzes this potential gap in a specific sector, the textile sector, which is characterized to have a global supply chain.

The results obtained associated with RQ1 confirm the increased awareness which companies have towards the environment challenges clearly encouraged by public institutions and media. In this vein, it is aligned with research which highlights the relevance of institutional and stakeholder pressure for the development of environmental management strategies (Colwell and Joshi, 2013; Zhu et al., 2013; Liao, 2017; and Arena et al., 2018, among others).

At the same time, the results related to RQ2 demonstrate the existence of an important gap between corporate environmental management and sectoral environmental hotspots. This implies that companies could be managing environmental issues related to global environmental concerns, but ignoring those environmental issues actually relevant from a technical view, according to their activity nature and geographical location. A potential risk in this circumstance is to advance in corporate sustainability results without significant impacts in the sustainability of the planet and society as a whole, producing what Dyllick and Muff (2016) call as 'a "big disconnect" between micro-level progress and macro-level deterioration'. Future research could analyze the rationale behind this evidence. Potential arguments could be related to the shortcomings showed by companies in their materiality analysis regarding sustainability issues (León et al., 2016). Other feasible explanation could be the little references to environmental science by companies' reports as a guide in determining sustainability actions (Landrum and Ohsowski, 2018).

Another remarkable finding of this study shows that the first phases of the textile life cycle are where most of the environmental impacts are created; however, these phases present the greatest corporate information shortfall. This result is consistent with the findings of Damert and Baumgartner (2018), who determined that companies whose business activities entail a greater interaction with the end consumer tend to be more active in terms of clime change mitigation efforts.

Finally, it is important to note that the lack of information could actually be more severe, since this study has chosen the "best companies" in terms of sustainability information in each phase of the textile life cycle. This lack of information affects the sustainability assessment process 
limiting the scope and depth of the analysis that could be carried out, making difficult the obtention of a comprehensive result and the development of sound decisions in a sustainability context.

This study highlights a weakness in the corporate management and reporting systems with respect to the internalization of environmental impacts and the scope of the impacts beyond the legal limits of the company. This shows a clear disconnection between theory and practice on the sustainable supply chain management. Therefore, the results entail a bias in the decisionmaking process. If market actors only consider the environmental information reported by companies as an input to reach a judgment, since the reported information does not cover the whole impact under life cycle thinking, market actors could develop ineffective environmental management to improve sustainability. In this context, on the one hand, companies should integrate the environmental commitment to manage their environmental hotspots, the crucial impacts along the supply chain that contribute to achieve industry transformation towards sustainability. On the other hand, international organizations, when formulating their policies and initiatives, should consider the environmental management complexity by adopting a lifecycle thinking approach, which takes into account the most relevant impacts in each life-cycle phase.

From a communication perspective of the relevant information for organizational decision making under life-cycle thinking, the connection with the most important hotspots might serve the purpose of "warning" an organization about those management areas to which attention should be turned in order to improve its environmental performance (OEF). It is expected that the most relevant impact categories shall be the object of the sustainable communication phase of sectoral companies, whilst the most relevant life-cycle phases could be used for an efficient management to efficiently reduce impacts throughout the life cycle.

\section{Conclusions}

The sustainable management concept has been widely applied not only from a company's internal operations perspective, but also considering the whole supply chain. The institutional pressures such as stakeholder's consciousness, competitive advantage, or the international political agenda are shown as enablers for organizations to adopt sustainability management practices. However, if sustainability management is not extended along the supply chain, the sustainability measures and reports show a limited and biased picture of the real impacts.

This necessity is more evident in global supply chains. In this respect, textile industry is considered as one of the global supply chains with major contribution to environmental pollution. This paper aims to analyze whether environmental measurement and reporting practices developed by companies that comprise a global textile supply chain, are aligned with global environmental challenges and sectoral hotspots. The set of impact categories of the European Organization Environmental Footprint have been used as a referent to classify the environmental impacts. The first research question (RQ1) has been addressed exploring whether the environmental indicators from a sample of 31 companies belonging to different textile product life cycle phases were connected with the global environmental challenges derived from the SDGs and Planetary Boundaries. The second research question (RQ2) has been answered analyzing whether the environmental indicators from the companies are aligned with the textile 
environmental hotspots, identified thought the technical tool SimaPro that allows their quantification along the life cycle phases using different scenarios.

The results of this study show that the environmental indicators reported by companies present a consistency with the global environmental challenges and a disconnection with the hotspots of the textile supply chain. This possible disconnection could be addressed fostering the integration in the environmental management debate of the use of science-based decision tools like the environmental footprint, that helps industries and companies to identify their real impacts thought a life cycle analysis where the supply chains of the companies are fully considered.

There are some limitations in the development of this research. The most import one is connected with the sources of information about managerial practices along the whole supply chain. As the research was developed with the public information provided by a sample of companies for each phase of the cotton-made t-shirt life cycle, and considering that indicators are not standardized, a degree of interpretation was required in the work of analysists. A second remarkable limitation is connected with the use of technical databases, in this case, Ecoinvent. It is necessary to take into account the fact that life-cycle assessment databases present limited information on certain economic activities and geographical areas; which means carrying out simulations that simplify a reality. More efforts from academia and practice should be increased to broaden the scope and improve the quality of information available in reporting tools and databases. The scope of the present research was limited to the assessment of environmental issues instead of dealing with corporate sustainability.

Further studies on this topic could focus on other sustainability dimensions such as the social and the economic ones. These studies could also repeat the hotspots analysis considering all sustainability dimensions with the aim of identifying the main aspects to be improved from a holistic approach. This research could be extrapolated to other sectors which cause considerable environmental and social concerns along the global supply chain such as the mobile phone sector. In addition, this work could be complemented with new scenarios by considering multiproduct companies with the aim of testing the robustness of the results.

Finally, this study poses additional challenges to incorporate technical impact indicators from a life-cycle thinking approach in the sustainability management systems. This could be done by including generally accepted footprint indicators such as the OEF which may complement the corporate reporting system with technical sustainability information and may create new reporting sustainability models for businesses.

\section{Acknowledgements}

This paper is supported by European Union's Horizon 2020 Research and Innovation Programme under Grant Agreement No. 693642, project SMART (Sustainable Market Actors for Responsible Trade). 


\section{References}

Adams, C. A., and Frost, G. R. (2008), "Integrating sustainability reporting into management practices", Accounting Forum, Vol. 32, No. 4, pp. 288-302.

Arcese, G., Lucchetti, M.C. and Massa, I. (2017), "Modeling Social Life Cycle Assessment framework for the Italian wine sector" Journal of Cleaner Production, Vol. 140, pp. $1027-1036$.

Arena, M., Azzone, G., and Mapelli, F. (2018), "What drives the evolution of Corporate Social Responsibility strategies? An institutional logics perspective", Journal of cleaner production, Vol. 171, pp. 345-355.

Bamonti, S., Spinelli, R., and Bonoli, A. (2016). "Environmental Footprint in the Production of Recycled Wool", Environmental Engineering \& Management Journal (EEMJ), Vol.15, No.9, pp. 1923-1931.

Barbosa-Póvoa, A. P., da Silva, C., \& Carvalho, A. (2018). "Opportunities and challenges in sustainable supply chain: An operations research perspective", European Journal of Operational Research, Vol. 268, No. 2, pp. 399-431.

Baydar, G., Ciliz, N., and Mammadov, A. (2015). "Life cycle assessment of cotton textile products in Turkey", Resources, Conservation and Recycling, Vol.104, pp. 213-223.

Beton, A., Dias, D., Farrant, L., Gibon, T., Le Guern, Y., Desaxce, M., Perwueltz, A, Boufeteh I., Woldf O., Kougoulis M.C, Cordella, M., and Dodd N. (2014). "Environmental improvement potential of textiles (IMPRO-Textiles)". European Commission. Available online:

http://publications.jrc.ec.europa.eu/repository/bitstream/JRC85895/impro\%20textiles fi nal\%20report\%20edited_pubsy\%20web.pdf (accessed on 25 February 2019).

Bevilacqua, M., Ciarapica, F. E., Mazzuto, G., and Paciarotti, C. (2014). "Environmental analysis of a cotton yarn supply chain", Journal of Cleaner Production, Vol. 82, pp. 154165.

Blass, V., and Corbett, C. J. (2018), "Same supply chain, different models: Integrating perspectives from life cycle assessment and supply chain management". Journal of Industrial Ecology, Vol. 22, No. 1, pp. 18-30.

Brandenburg, M., Govindan, K., Sarkis, J., \& Seuring, S. (2014). "Quantitative models for sustainable supply chain management: Developments and directions", European journal of operational research, Vol. 233, pp. 299-312

Choudhury, A. R. (2014), "Environmental Impacts of the Textile Industry and Its Assessment Through Life Cycle Assessment", In: Muthu S. (eds) Roadmap to Sustainable Textiles and Clothing. Textile Science and Clothing Technology, pp. 1-39. Springer, Singapore.

Cohen, J. R., Holder-Webb, L. L., Nath, L., and Wood, D. (2012). Corporate reporting of nonfinancial leading indicators of economic performance and sustainability. Accounting Horizons, 26(1), 65-90.

Colwell, S.R. and Joshi, A.W. (2013), "Corporate ecological responsiveness: antecedent effects of institutional pressure and top management commitment and their impact on organizational performance", Business Strategy and the Environment, Vol. 22 No. 2, pp. 73-91.

Cûcêk, L., Klemeš, J.J., Kravanja, Z. (2012), "A review of footprint analysis tools for monitoring impacts on sustainability", Journal of Cleaner Production, Vol. 34, pp. 9-20.

Dahlbo, H., Aalto, K., Eskelinen, H., and Salmenperä, H. (2017), "Increasing textile circulation-consequences and requirements", Sustainable Production and Consumption, Vol. 9, pp. 44-57.

Damert, M., and Baumgartner, R. J. (2018). "External Pressures or Internal Governance-What Determines the Extent of Corporate Responses to Climate Change?", Corporate social responsibility and environmental management, Vol. 25, pp. 473-488. 
Dauvergne P. and Alger J., (2018) A Research Agenda for Global Environmental Politics, Edward Elgar Publishing Limited, Cheltenham, UK; Northampton, USA.

Desore, A., and Narula, S. A. (2018), "An overview on corporate response towards sustainability issues in textile industry", Environment, Development and Sustainability, Vol. 20, No. 4, pp. 1439-1459.

Diabat, A., Kannan, D., and Mathiyazhagan, K. (2014). "Analysis of enablers for implementation of sustainable supply chain management-A textile case", Journal of cleaner production, Vol. 83, pp. 391-403.

Erdil, A., and Taçgın, E. (2018), "Potential Risks and Their Analysis of the Apparel \& Textile Industry in Turkey: A Quality-Oriented Sustainability Approach" Fibres \& Textiles in Eastern Europe, Vol. 6, No. 132, pp. 30-42.

Esteve-Turrillas, F. A., and de la Guardia, M. (2017), "Environmental impact of Recover cotton in textile industry" Resources, Conservation and Recycling, Vol. 116, pp. 107-115.

European Commission (2013) "2013/179/EU: Commission Recommendation of 9 April 2013 on the use of common methods to measure and communicate the life cycle environmental performance of products and organisations", Text with EEA relevance Available at: http://eur-lex.europa.eu/legal-content/EN/TXT/?uri=CELEX:32013H0179 (Accessed on 25 February 2019)

European Commission (2016) "Product Environmental Footprint Pilot Guidance Guidance for the implementation of the EU Product Environmental Footprint (PEF) during the Environmental Footprint (EF) pilot phase". Version 5.2 - February 2016. Available at: http://ec.europa.eu/environment/eussd/smgp/pdf/Guidance products.pdf (Accessed on 25 February 2019)

European Union (2011) EU, "No 1007/2011 of the European Parliament and of the Council of 27 September 2011 on textile fibre names and related labelling and marking of the fibre composition of textile products and repealing Council Directive 73/44/EEC and Directives 96/73/EC and 2008/121/EC of the European Parliament and of the Council" (Text with EEA relevance), Available at: https://eur-lex.europa.eu/legalcontent/EN/TXT/PDF/?uri=CELEX:02011R1007-20130701\&from=EN (accessed on 25 February 2019)

Fandel, G., and Stammen, M. (2004). "A general model for extended strategic supply chain management with emphasis on product life cycles including development and recycling", International Journal of Production Economics, Vol. 89, No. 3, pp. 293-308.

Farrant, L., Olsen, S. I., and Wangel, A. (2010), "Environmental benefits from reusing clothes" The International Journal of Life Cycle Assessment, Vol. 15, No. 7, pp. 726-736.

Garrido Acevedo, S., Carvalho, H., Ferreira, L. M., and Matias, J. C. (2017). "A proposed framework to assess upstream supply chain sustainability", Environment, development and sustainability, Vol. 19 No. 6, pp. 2253-2273.

Gunarathne, Nuwan, and Ki-Hoon Lee (2019), "Institutional pressures and corporate environmental management maturity" Management of Environmental Quality: An International Journal, Vol. 30, No.1, pp. 157-175.

Halog, A., Manik, Y. (2011), “Advancing integrated systems modelling framework for life cycle sustainability assessment”, Sustainability, Vol. 3, pp. 469-499.

Hasanbeigi, A., and Price, L. (2015), "A technical review of emerging technologies for energy and water efficiency and pollution reduction in the textile industry", Journal of Cleaner Production, Vol. 95, pp. 30-44.

Hoogmartens, R., Van Passel, S., Van Acker, K., Dubois, M. (2014), "Bridging the gap between LCA, LCC and CBA as sustainability assessment tools" Environmental Impact Assessment Review, Vol. 48, pp. 27-33. 
Koberg, E., and Longoni, A. (2019), "A systematic review of sustainable supply chain management in global supply chains" Journal of Cleaner Production, Vol. 207, pp. 10841098

Köksal, D., Strähle, J., Müller, M., and Freise, M. (2017), "Social sustainable supply chain management in the textile and apparel industry-A literature review", Sustainability, Vol. 9, No. 100, pp. 1-32.

Kumar, V., Hallqvist, C., and Ekwall, D. (2017) "Developing a framework for traceability implementation in the textile supply chain" Systems, Vol. 5, No. 2, 33, pp. 1-21.

Lambooy, T., Bosman, M., Solaimani, S. (2017) "D3.1 Sustainability Hot Spot Analysis of two ready-made garments" Public Report, SMART H2020 Project, Available online: https://www.smart.uio.no/publications/reports/d3.1.-revised-hotspots-analysis-wp3.pdf (accessed on 25 February 2019).

Landrum, N. E., and Ohsowski, B. (2018), "Identifying worldviews on corporate sustainability: A content analysis of corporate sustainability reports", Business Strategy and the Environment, Vol. 27, pp. 128-151.

León, R., Ferrero-Ferrero, I. and Muñoz-Torres, M. J. (2016), "Environmental Performance Assessment in the Apparel Industry. A Materiality-Based Approach", Modeling and Simulation in Engineering, Economics and Management. MS 2016. Lecture Notes in Business Information Processing, Vol. 254, pp. 51-60.

Liao, Z. (2018), "Institutional pressure, knowledge acquisition and a firm's environmental innovation", Business Strategy and the Environment, Vol.27, pp. 849-857.

Liu, X., Klemeš, J. J., Varbanov, P. S., Čuček, L., and Qian, Y. (2017), "Virtual carbon and water flows embodied in international trade: a review on consumption-based analysis" Journal of Cleaner Production, Vol. 146, 20-28.

Maas, K., Schaltegger, S., and Crutzen, N. (2016), "Integrating corporate sustainability assessment, management accounting, control, and reporting", Journal of Cleaner Production, Vol. 136, pp. 237-248.

Martins, C. L., and Pato, M. V. (2019). "Supply chain sustainability: A tertiary literature review", Journal of Cleaner Production, https://doi.org/10.1016/j.jclepro.2019.03.250

Moneva, J. M., Rivera-Lirio, J. M., and Muñoz-Torres, M. J. (2007), "The corporate stakeholder commitment and social and financial performance", Industrial management \& data systems, 107(1), pp. 84-102.

Muñoz-Torres, M. J., Fernández-Izquierdo, M. Á., Rivera-Lirio, J. M., Ferrero-Ferrero, I., Escrig-Olmedo, E., Gisbert-Navarro, J. V., and Marullo, M. C. (2018a) "An assessment tool to integrate sustainability principles into the global supply chain" Sustainability, Vol. 10, No. 2, 535, pp.1-20

Muñoz-Torres, M.J., Fernandez-Izquierdo, M.A., Rivera-Lirio, J.M., Ferrero-Ferrero, I., EscrigOlmedo, E., Marullo, M.C., Gisbert-Navarro, J.V. (2017) "D5.1 List of Issues to Be Considered under Life Cycle Thinking, Public Report, SMART H2020 Project", Available online: http://www.smart.uio.no/research/life-cycle-thinking---issues-to-beconsidered.pdf (accessed on 25 February 2019).

Muñoz-Torres, M.J., Fernandez-Izquierdo, M.A., Rivera-Lirio, J.M., Ferrero-Ferrero, I., EscrigOlmedo, E., Gisbert-Navarro, J.V. (2018b) "D5.2 List of best practices and KPIs of the textile products life cycle" Public Report, SMART H2020 Project, Available online: https://www.smart.uio.no/publications/reports/d5.2 final draft august-new.pdf (accessed on 25 February 2019).

Muthu, S. S., Li, Y., Hu, J. Y., and Ze, L. (2012), "Carbon footprint reduction in the textile process chain: recycling of textile materials", Fibers and Polymers, Vol. 13, No.8, pp.1065-1070.

Neppach, Simone, Katia RA Nunes, and Liselotte Schebek. (2017), "Organizational environmental footprint in German construction companies." Journal of Cleaner Production Vol. 142, pp.78-86.

Nieminen, E., Linke, M., Tobler, M., and Vander Beke, B. (2007), “EU COST Action 628: life cycle assessment (LCA) of textile products, eco-efficiency and definition of best available 
technology (BAT) of textile processing", Journal of Cleaner Production, Vol. 15, No. 13-14, pp.1259-1270.

Parisi, M. L., Fatarella, E., Spinelli, D., Pogni, R., and Basosi, R. (2015), "Environmental impact assessment of an eco-efficient production for coloured textiles" Journal of Cleaner Production, Vol. 108, pp. 514-524.

Pelletier, Nathan, et al. (2014), "The European Commission Organisation Environmental Footprint method: comparison with other methods, and rationales for key requirements" The International Journal of Life Cycle Assessment Vol. 19, No.2, pp.387-404.

Piontek, F. M., and Müller, M. (2018), "Literature Reviews: Life Cycle Assessment in the Context of Product-Service Systems and the Textile Industry" Procedia CIRP, Vol. 69, No. 1, pp.758-763.

Rajesh, R. (2018). "On sustainability, resilience, and the sustainable-resilient supply networks", Sustainable Production and Consumption, Vol. 15, pp. 74-88.

Rajesh, R. (2019). "A fuzzy approach to analyzing the level of resilience in manufacturing supply chains", Sustainable Production and Consumption, Vol. 18, pp. 224-236.

Rana, S., Karunamoorthy, S., Parveen, S., and Fangueiro, R. (2015), "Life cycle assessment of cotton textiles and clothing" In Handbook of Life Cycle Assessment (LCA) of Textiles and Clothing (pp. 195-216). Woodhead Publishing.

Rockström, Johan, et al. (2009). "Planetary boundaries: exploring the safe operating space for humanity" Ecology and Society Vol. 14, No.2:32.

Roos, S., Zamani, B., Sandin, G., Peters, G. M., and Svanström, M. (2016), “A life cycle assessment (LCA)-based approach to guiding an industry sector towards sustainability: the case of the Swedish apparel sector", Journal of Cleaner Production, Vol. 133, pp. 691-700.

Schaltegger, S., and Burritt, R. (2014). Measuring and managing sustainability performance of supply chains: Review and sustainability supply chain management framework. Supply Chain Management: An International Journal, 19(3), 232-241.

Sarkis, J. (2019). "The Handbook on the Sustainable Supply Chain: an introduction". In Handbook on the Sustainable Supply Chain. Edward Elgar Publishing.

Sarkis, J., Zhu, Q., and Lai, K. H. (2011), "An organizational theoretic review of green supply chain management literature", International Journal of Production Economics, Vol. 130, No. 1, pp.1-15.

Seuring, S. (2013), "A review of modeling approaches for sustainable supply chain management" Decision Support Systems, Vol. 54, No.4, pp.1513-1520.

Seyoum, B. (2010), "Trade liberalization in textiles and clothing and developing countries: an analysis with special emphasis on the US import Market", The International Trade Journal, Vol. 24, No.2, pp.149-181.

Souza, R.G., Rosenhead, J., Salhofer, S.P., Valle, R.A.B., Lins, M.P.E. (2015), "Definition of sustainability impact categories based on stakeholder perspectives", Journal of Cleaner Production, Vol. 105, pp.41-51.

Steinberger, J. K., Friot, D., Jolliet, O., and Erkman, S. (2009). "A spatially explicit life cycle inventory of the global textile chain" The International Journal of Life Cycle Assessment, Vol. 14, No.5, pp.443-455.

Tasdemir, C., Gazo, R., and Quesada, H. J. (2019). Sustainability benchmarking tool (SBT): theoretical and conceptual model proposition of a composite framework. Environment, Development and Sustainability, 1-43, forthcoming, doi: 0.1007/s10668-019-00512-3

Taticchi, P., Tonelli, F., \& Pasqualino, R. (2013). "Performance measurement of sustainable supply chains: A literature review and a research agenda" International Journal of Productivity and Performance Management, Vol. 62, pp.782-804.

Testa, F., Nucci, B., Iraldo, F., Appolloni, A., and Daddi, T. (2017) "Removing obstacles to the implementation of LCA among SMEs: A collective strategy for exploiting recycled wool" Journal of Cleaner Production, Vol. 156, pp.923-931. 
Tsalis, T., Avramidou, A., Nikolaou, I.E. (2017), "A social LCA framework to assess the corporate social profile of companies: Insights from a case study", Journal of Cleaner Production, Vol. 164, pp.1665-1676.

Tseng, M. L., Islam, M. S., Karia, N., Fauzi, F. A., and Afrin, S. (2019), "A literature review on green supply chain management: Trends and future challenges", Resources, Conservation and Recycling, Vol. 141, pp.145-162.

Uluskan, M., and Godfrey, A. B. (2018) "Business environment-supply chain framework and benchmarking supply chain structures: Haiti versus China", Benchmarking: An International Journal, Vol. 25, No.8, pp.3021-3044.

UNEP-SETAC (2017) "Hotspots Analysis. An overarching methodological framework and guidance for product and sector level application" https://www.lifecycleinitiative.org/new-hotspots-analysis-methodological-frameworkand-guidance/

van der Velden, N. M., Patel, M. K., and Vogtländer, J. G. (2014), "LCA benchmarking study on textiles made of cotton, polyester, nylon, acryl, or elastane", The International Journal of Life Cycle Assessment, Vol. 19, No.2, pp.331-356.

Wu, G. C., Ding, J. H., and Chen, P. S. (2012). The effects of GSCM drivers and institutional pressures on GSCM practices in Taiwan's textile and apparel industry. International Journal of Production Economics, 135(2), 618-636.

Xu, L., Mathiyazhagan, K., Govindan, K., Haq, A. N., Ramachandran, N. V., and Ashokkumar, A. (2013). Multiple comparative studies of green supply chain management: pressures analysis. Resources, Conservation and Recycling, 78, 26-35.

Zamani, B., Svanström, M., Peters, G., and Rydberg, T. (2015), “A carbon footprint of textile recycling: A case study in Sweden", Journal of Industrial Ecology, Vol. 19(4), pp.676687.

Zhang, Y., Kang, H., Hou, H., Shao, S., Sun, X., Qin, C., and Zhang, S. (2018), "Improved design for textile production process based on life cycle assessment", Clean Technologies and Environmental Policy, Vol. 20, No.6, pp.1355-1365.

Zimon, D., and Domingues, P. (2018), "Proposal of a Concept for Improving the Sustainable Management of Supply Chains in the Textile Industry", Fibers \& Textiles in Eastern Europe, Vol. 26, No.2(128), pp.8-12.

Zhu, Q., Cordeiro, J. and Sarkis, J. (2013), "Institutional pressures, dynamic capabilities and environmental management systems: investigating the ISO 9000-environmental management system implementation linkage", Journal of Environmental Management, Vol. 114, pp. 232-242. 


\section{FIGURES}

Figure 1: Flow chart of the study

Literature Review on Supply Chain Sustainability; Textile Supply Chains \& Environmental Impacts Management in Textile Sector

RQ1: Are companies which belong to different textile life-cycle stages, measuring and reporting relevant environmental issues for supply chain management, in accordance with global environmental challenges?
RQ2: Are companies which belong to different textile life-cycle stages, measuring and reporting relevant environmental issues for supply chain management, in accordance with textile industry environmental hotspots?

\section{Research Design}

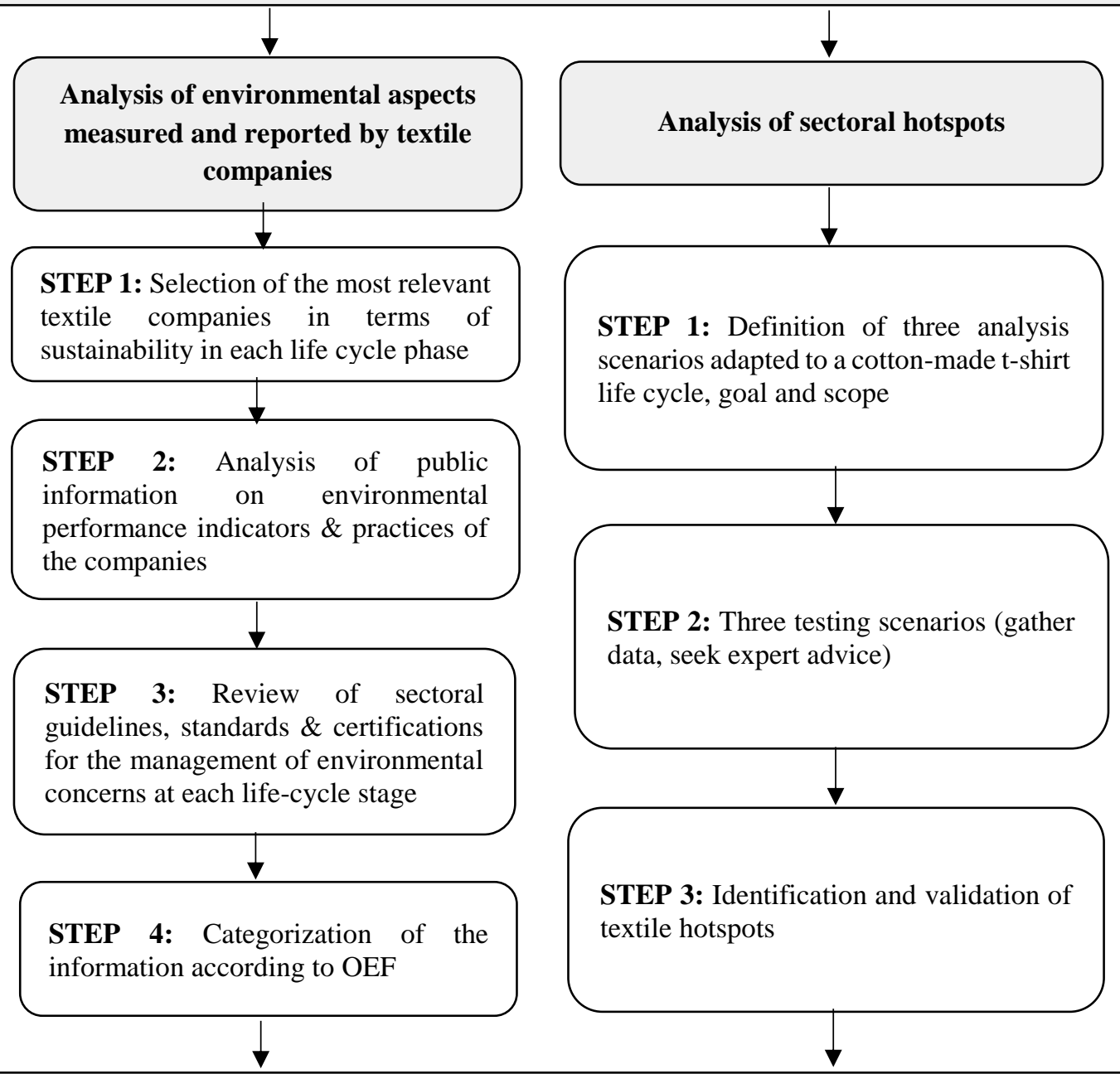

Results analysis and Discussion

\section{Conclusion, Limitations \& Future Scope}


Figure 2. Textile product life cycle

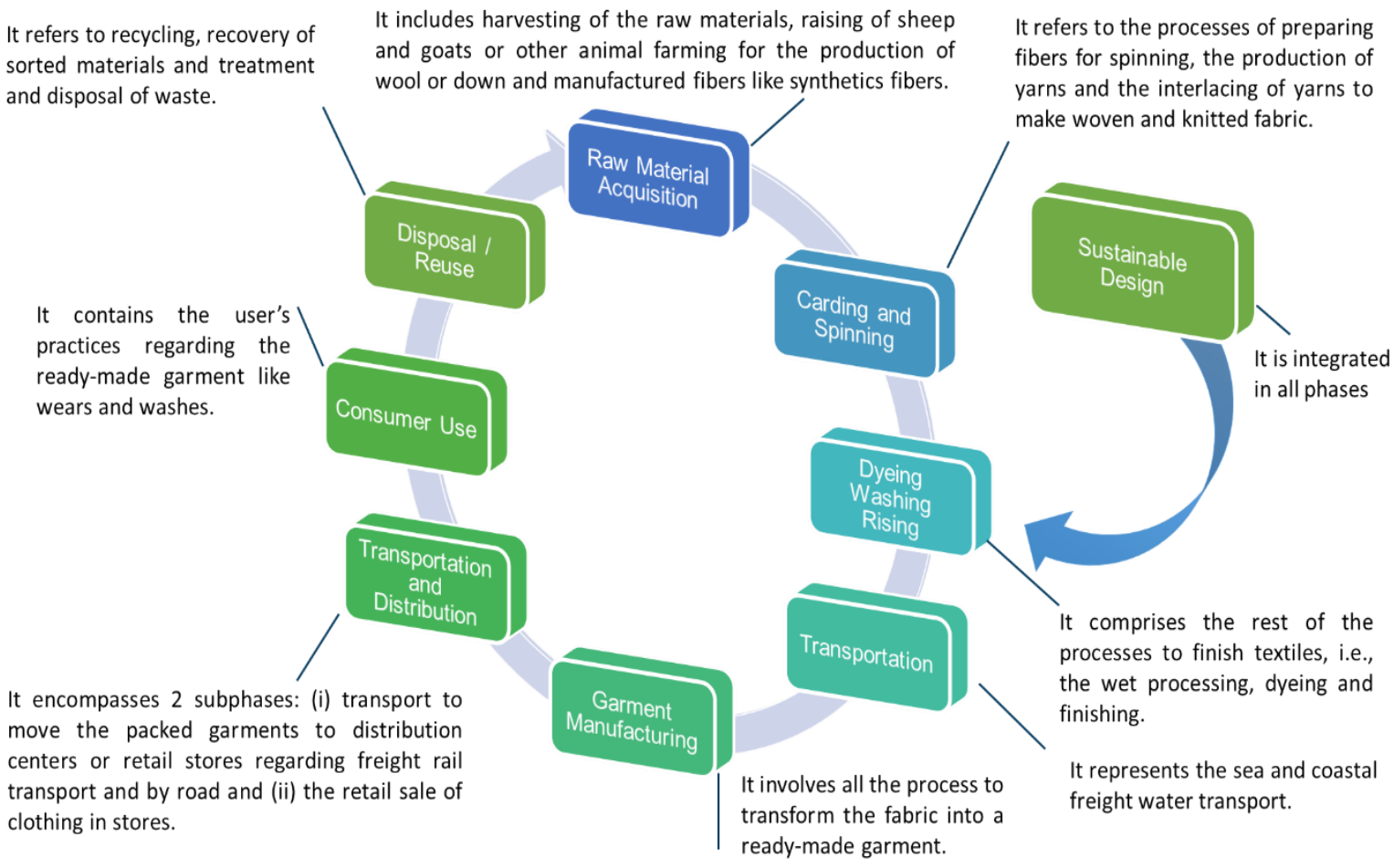

Source: Own creation based on Muñoz-Torres et al. (2018b)

Figure 3. Number of organizations and economic activities analyzed by the textile product life cycle

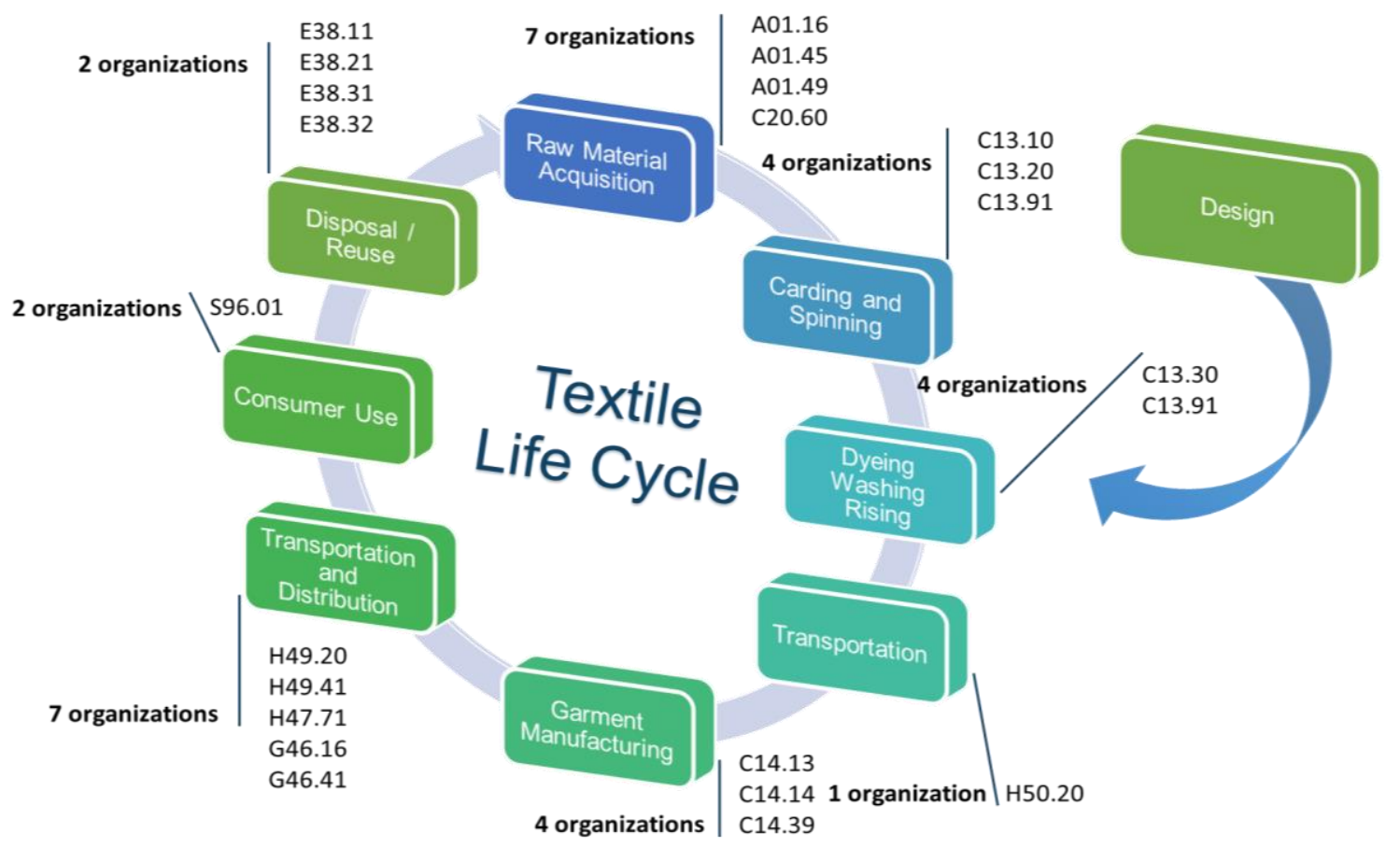

Source: Muñoz-Torres et al. (2018b) 
Figure 4. Cotton-made t-shirt life cycle

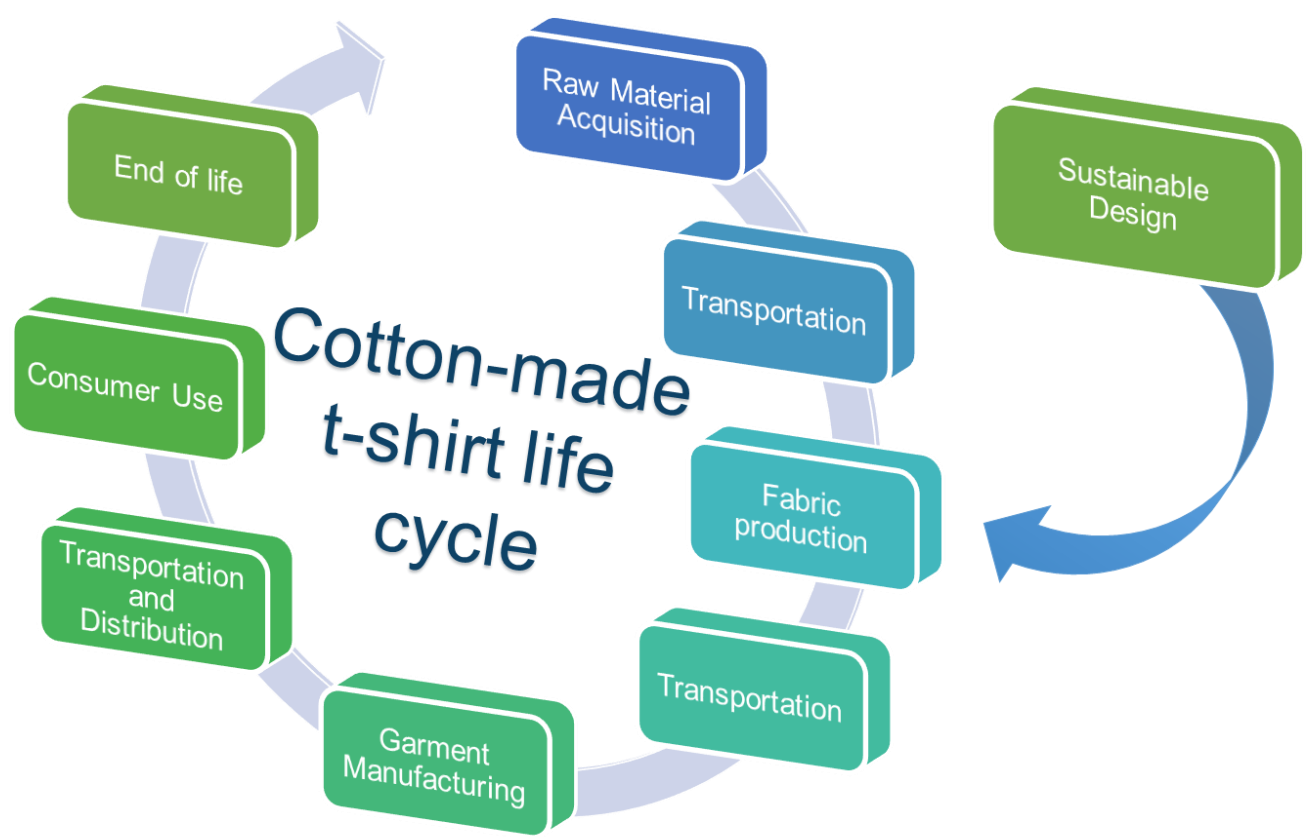

Source: Own creation

Figure 5. Textile industry environmental impact categories by scenarios

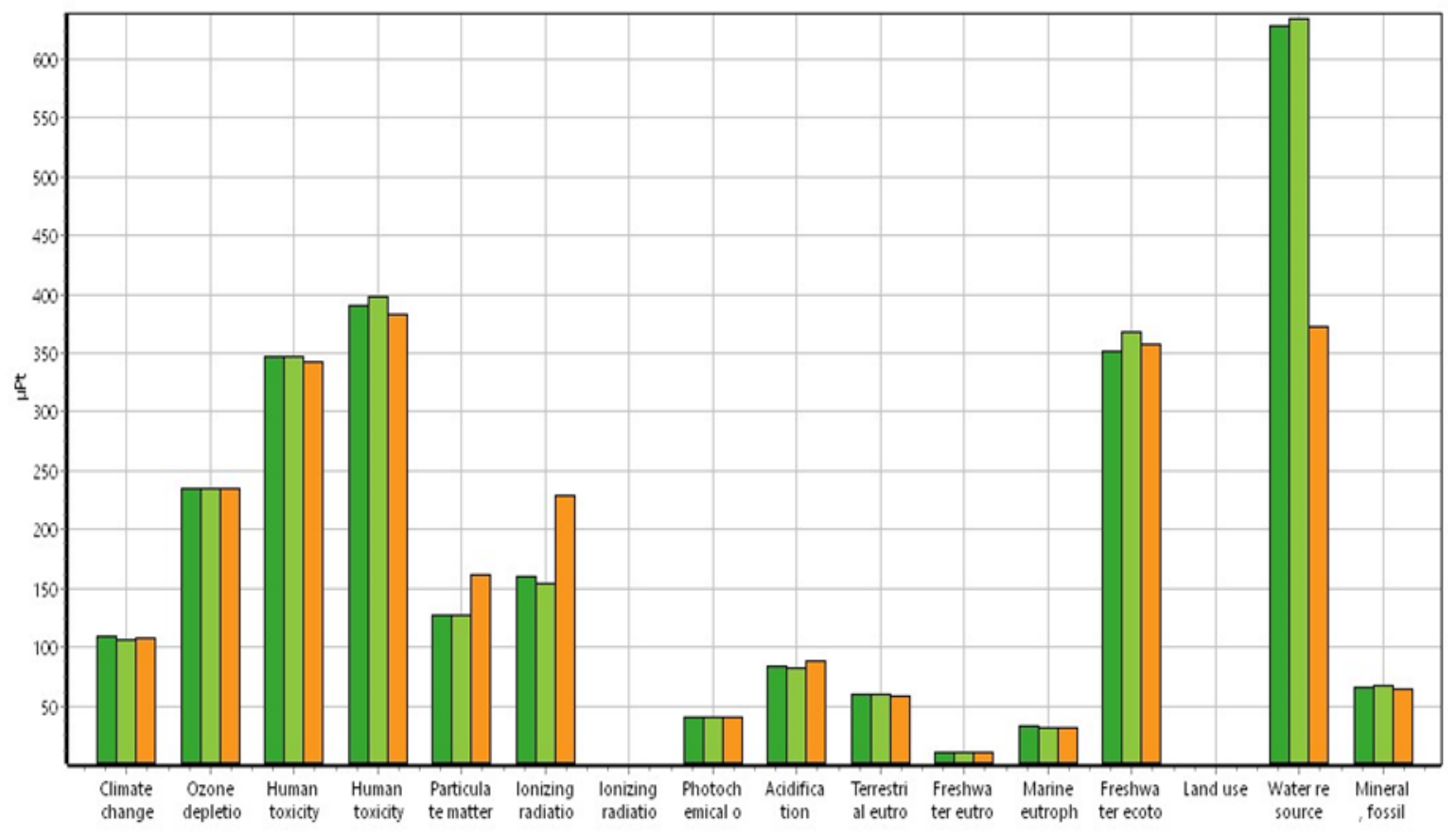

口 Cotton-made T-shirt (SCENARIO 1-without reuse) $\square$ Cotton-made T-shirt (SCENARIO 2-with reuse) Q Cotton-made T-shirt (SCENARIO 3-USA)

Source: SimaPro simulations (Simulation data: February 2019) 


\section{TABLES}

Table 1 Relationship between OEF impact categories, Planetary Boundaries and SDGs

\begin{tabular}{|c|c|c|}
\hline OEF Impact categories & Planetary Boundaries & SDGs \\
\hline Climate change & $\begin{array}{l}\text { Climate change; } \\
\text { Ocean acidification; } \\
\text { Nitrogen and phosphorus inputs } \\
\text { to the biosphere and oceans; } \\
\text { Biodiversity loss }\end{array}$ & $\begin{array}{l}\text { 7. Affordable and clean energy; } \\
\text { 11. Sustainable cities and communities; } \\
\text { 12. Responsible consumption and } \\
\text { production; } \\
\text { 13. Climate action }\end{array}$ \\
\hline Ozone depletion & $\begin{array}{l}\text { Stratospheric ozone Depletion; } \\
\text { Biodiversity loss; }\end{array}$ & $\begin{array}{l}\text { 12. Responsible consumption and } \\
\text { production }\end{array}$ \\
\hline $\begin{array}{l}\text { Human toxicity - cancer } \\
\text { effects }\end{array}$ & $\begin{array}{l}\text { Chemical pollution (unable to } \\
\text { suggest boundary yet) }\end{array}$ & 3. Good health and well-being \\
\hline $\begin{array}{l}\text { Human toxicity - non- } \\
\text { cancer effects }\end{array}$ & $\begin{array}{l}\text { Chemical pollution (unable to } \\
\text { suggest boundary yet) }\end{array}$ & 3. Good health and well-being \\
\hline Particulate matter & $\begin{array}{l}\text { Atmospheric aerosol loading } \\
\text { (unable to suggest boundary yet); } \\
\text { Chemical pollution (unable to } \\
\text { suggest boundary yet) }\end{array}$ & \\
\hline $\begin{array}{l}\text { Ionizing radiation - } \\
\text { human health effects }\end{array}$ & $\begin{array}{l}\text { Chemical pollution (unable to } \\
\text { suggest boundary yet) }\end{array}$ & 7. Affordable and clean energy \\
\hline \multicolumn{3}{|l|}{$\begin{array}{l}\text { Photochemical ozone } \\
\text { formation }\end{array}$} \\
\hline Acidification & $\begin{array}{l}\text { Biodiversity loss; } \\
\text { Chemical pollution (unable to } \\
\text { suggest boundary yet) }\end{array}$ & 7. Affordable and clean energy \\
\hline Terrestrial eutrophication & $\begin{array}{l}\text { Nitrogen and phosphorus inputs to } \\
\text { the biosphere and oceans; } \\
\text { Biodiversity loss }\end{array}$ & 15. Life on land \\
\hline $\begin{array}{l}\text { Freshwater } \\
\text { eutrophication }\end{array}$ & $\begin{array}{l}\text { Ocean acidification; Nitrogen and } \\
\text { phosphorus inputs to the } \\
\text { biosphere and oceans; } \\
\text { Biodiversity loss }\end{array}$ & $\begin{array}{l}\text { 6. Clean water and sanitation; } \\
\text { 14. Life below water }\end{array}$ \\
\hline Freshwater ecotoxicity & $\begin{array}{l}\text { Biodiversity loss; } \\
\text { Chemical pollution (unable to } \\
\text { suggest boundary yet) }\end{array}$ & $\begin{array}{l}\text { 11. Sustainable cities and communities; } \\
\text { 13. Climate action; } \\
\text { 14. Life below water }\end{array}$ \\
\hline Water resource depletion & Global freshwater use & $\begin{array}{l}\text { 6. Clean water and sanitation; } \\
\text { 14. Life below water }\end{array}$ \\
\hline $\begin{array}{l}\text { Mineral fossil and } \\
\text { resource depletion }\end{array}$ & $\begin{array}{l}\text { Chemical pollution (unable to } \\
\text { suggest boundary yet) }\end{array}$ & 15. Life on land \\
\hline Land use & $\begin{array}{l}\text { Land system change; Biodiversity } \\
\text { loss; }\end{array}$ & $\begin{array}{l}\text { 12. Responsible consumption and } \\
\text { production; } \\
\text { 13. Climate action; } \\
\text { 15. Life on land }\end{array}$ \\
\hline
\end{tabular}

Source: Own creation based on Muñoz-Torres et al. (2017). 
Table 2. Life-cycle phases of the cotton t-shirt without reuse

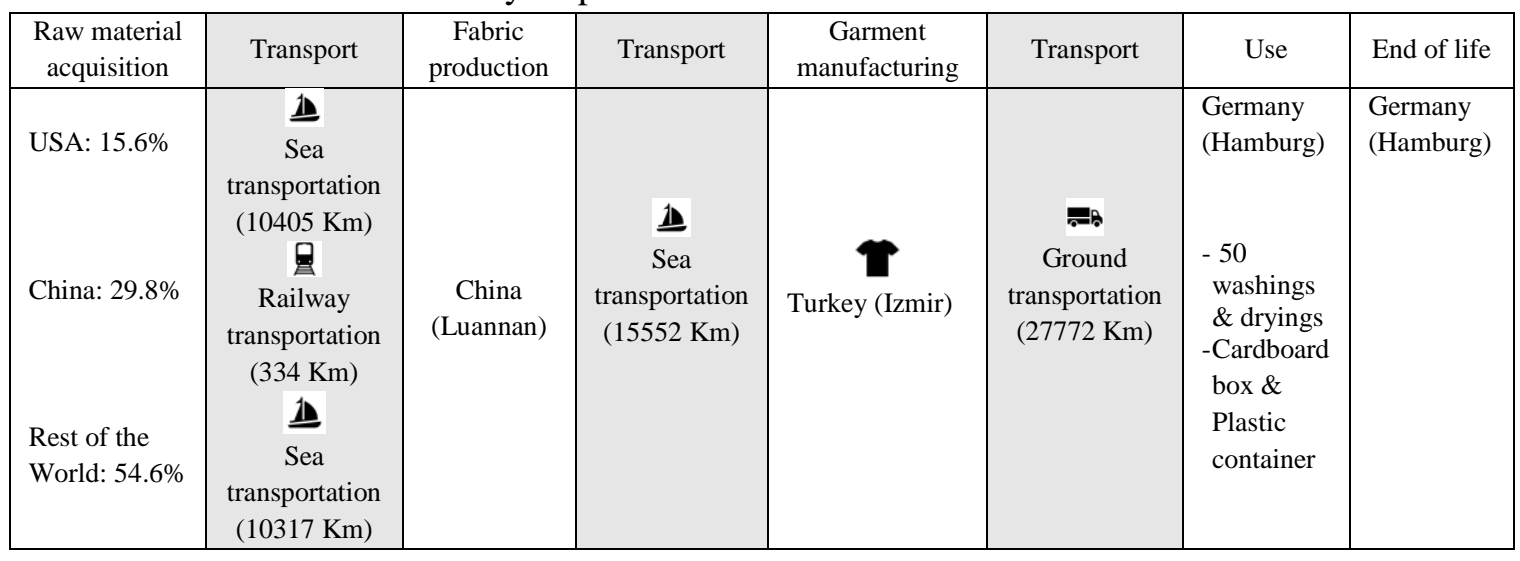

Table 3. Life-cycle phases of the cotton t-shirt with reuse

\begin{tabular}{|c|c|c|c|c|c|c|c|c|c|}
\hline $\begin{array}{l}\text { Rawmaterial } \\
\text { acquisition }\end{array}$ & Transport & $\begin{array}{c}\text { Fabric } \\
\text { production }\end{array}$ & Transport & $\begin{array}{c}\text { Gament } \\
\text { manufacturing }\end{array}$ & Transport & Use & Transport & Reuse & End oflife \\
\hline USA: $15.6 \%$ & $\begin{array}{c}\underline{\boldsymbol{N}} \\
\text { Sea } \\
\text { transpotataion }\end{array}$ & & & & & $\begin{array}{l}\text { Germany } \\
\text { (Hamburg) }\end{array}$ & 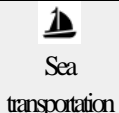 & $\begin{array}{l}\text { lvory } \\
\text { Coast } \\
\text { (Abidjan) }\end{array}$ & $\begin{array}{l}\text { Ivory Coast } \\
\text { (Abidjan) }\end{array}$ \\
\hline China: $29.8 \%$ & $\begin{array}{c}(10405 \mathrm{Km}) \\
\text { 昌 } \\
\text { Railway } \\
\text { transpottation } \\
\text { (334Km) } \\
\underline{\text { 1 }}\end{array}$ & $\begin{array}{c}\text { China } \\
\text { (Luannan) }\end{array}$ & $\begin{array}{c}\underline{1} \\
\text { Sea } \\
\text { transportation } \\
(15552 \mathrm{Km})\end{array}$ & Turkey(kmir) & $\begin{array}{c}\text { Ground } \\
\text { transpotation } \\
(2 T T 2 \mathrm{Km})\end{array}$ & $\begin{array}{l}40 \\
\text { washings \& } \\
\text { dryings } \\
\text { Cardboard } \\
\text { box\&Plasic } \\
\text { container }\end{array}$ & $(7357 \mathrm{Km})$ & $\begin{array}{l}\text { 25hand- } \\
\text { washings }\end{array}$ & \\
\hline $\begin{array}{l}\text { Rest of the } \\
\text { Woild: } \\
54.6 \%\end{array}$ & $\begin{array}{c}\text { Sea } \\
\text { transpotation } \\
(10317 \mathrm{Km})\end{array}$ & & & & & & & & \\
\hline
\end{tabular}

Table 4. Life-cycle phases of the cotton t-shirt in the USA

\begin{tabular}{|c|c|c|c|c|c|c|c|}
\hline $\begin{array}{c}\text { Raw material } \\
\text { acquisition }\end{array}$ & Transport & $\begin{array}{c}\text { Fabric } \\
\text { production }\end{array}$ & Transport & $\begin{array}{c}\text { Garment } \\
\text { manufacturing }\end{array}$ & Transport & Use & $\begin{array}{c}\text { End of } \\
\text { life }\end{array}$ \\
\hline $\begin{array}{c}\text { USA } \\
\text { (Lubbock, } \\
\text { Texas) }\end{array}$ & $\begin{array}{c}\text { Ground } \\
\text { transportation } \\
(2171 \mathrm{Km})\end{array}$ & $\begin{array}{c}\text { USA } \\
\text { (Gastonia, } \\
\text { North } \\
\text { Carolina) }\end{array}$ & $\begin{array}{l}\text { Ground } \\
\text { transportation } \\
(60 \mathrm{Km})\end{array}$ & $\begin{array}{c}\text { USA } \\
\text { (Gaffney, } \\
\text { South } \\
\text { carolina sur) }\end{array}$ & $\begin{array}{c}\text { 昌 } \\
\text { Railway } \\
\text { transportation } \\
(1108 \mathrm{Km})\end{array}$ & $\begin{array}{c}\text { USA } \\
\text { (New } \\
\text { York) } \\
50 \\
\text { washings } \\
\& \text { dryings } \\
\text {-Cardboard } \\
\text { box \& } \\
\text { Plastic } \\
\text { container }\end{array}$ & $\begin{array}{l}\text { USA } \\
\text { (New } \\
\text { York) }\end{array}$ \\
\hline
\end{tabular}


Table 5. Environmental Impact Categories and units

\begin{tabular}{|l|l|}
\hline Impact categories & Units \\
\hline Climate change & $\mathrm{Kg} \mathrm{C02} \mathrm{eq}$ \\
\hline Ozone depletion & $\mathrm{Kg} \mathrm{CFC}$ - 11 eq \\
\hline Human toxicity - cancer effects & CTUh \\
\hline Human toxicity - non- cancer effects & $\mathrm{CTUh}$ \\
\hline Particulate matter & $\mathrm{Kg} \mathrm{PM} 2.5 \mathrm{eq}$ \\
\hline Ionizing radiation - human health effects & $\mathrm{kBq}$ U235 eq \\
\hline Photochemical ozone formation & $\mathrm{Kg} \mathrm{NMVOC} \mathrm{eq}$ \\
\hline Acidification & $\mathrm{molc} \mathrm{H}+\mathrm{eq}$ \\
\hline Terrestrial eutrophication & $\mathrm{molc} \mathrm{N} \mathrm{eq}$ \\
\hline Freshwater eutrophication & $\mathrm{kg} \mathrm{P}$ eq \\
\hline Freshwater ecotoxicity & $\mathrm{CTUe}$ \\
\hline Water resource depletion & $\mathrm{m} 3$ water eq \\
\hline Mineral fossil and resource depletion & $\mathrm{kg} \mathrm{Sb}$ eq \\
\hline Land use & $\mathrm{kg} \mathrm{C} \mathrm{deficit}$ \\
\hline
\end{tabular}


Table 6. Environmental Footprint impact category and company indicators

\begin{tabular}{|l|l|l|l|l|l|l|l|l|}
\cline { 2 - 8 } \multicolumn{1}{c|}{} & \multicolumn{7}{c|}{ Life Cycle Phases } \\
\hline Impact Category & (1) & (2) & (3) & (4) & (5) & (6) & (7) & (8) \\
\hline Climate change & & & & & & & & \\
\hline Ozone depletion & & & & & & & & \\
\hline Ecotoxicity - fresh water & & & & & & & & \\
\hline Human toxicity - cancer effects & & & & & & & & \\
\hline Human toxicity - non- cancer effects & & & & & & & & \\
\hline Particulate matter/ respiratory inorganics & & & & & & & & \\
\hline Ionizing radiation - human health effects & & & & & & & \\
\hline Photochemical ozone formation & & & & & & & \\
\hline Acidification & & & & & & & & \\
\hline Terrestrial eutrophication & & & & & & & & \\
\hline Freshwater eutrophication & & & & & & & \\
\hline Water resource depletion & & & & & & & \\
\hline Mineral fossil and resource depletion & & & & & & & & \\
\hline Land Use & & & & & & & & \\
\hline
\end{tabular}

(1) Raw material acquisition

(2) Carding and spinning

(3) Dyeing, washing and rising

(4) Transportation

(5) Garment manufacturing

(6) Transportation and distribution

(7) Consumer use

(8) Disposal/reuse

$100 \%$ of the companies in the sample define at least one indicator linked with the impact category.

None of the companies define an indicator linked with the impact category.

Otherwise.

Source: Muñoz-Torres et al. (2018b) 
Table 7. Impact analysis results by scenarios

\begin{tabular}{|l|l|r|r|r|}
\hline \multicolumn{1}{|c|}{ Impact categories } & \multicolumn{1}{|c|}{ Units } & $\begin{array}{c}\text { Cotton-made T- } \\
\text { shirt (Scenario 1- } \\
\text { without reuse) }\end{array}$ & $\begin{array}{c}\text { Cotton-made T- } \\
\text { shirt (Scenario 2 } \\
\text { - with reuse) }\end{array}$ & $\begin{array}{c}\text { Cotton-made T- } \\
\text { shirt (Scenario 3 } \\
\text { - THE USA) }\end{array}$ \\
\hline Climate change & kg CO2 eq & 11.5087 & 11.2518 & 11.3871 \\
\hline Ozone depletion & kg CFC-11 eq & $4.30 \mathrm{E}-05$ & $4.29 \mathrm{E}-05$ & $4.31 \mathrm{E}-05$ \\
\hline Human toxicity - cancer effects & CTUh & $7.27 \mathrm{E}-08$ & $7.40 \mathrm{E}-08$ & $7.13 \mathrm{E}-08$ \\
\hline Human toxicity- non-cancer effects & CTUh & $8.07 \mathrm{E}-07$ & $8.07 \mathrm{E}-07$ & $7.97 \mathrm{E}-07$ \\
\hline Particulate matter & $\mathrm{kg} \mathrm{PM2.5} \mathrm{eq}$ & 0.0096 & 0.0096 & 0.0123 \\
\hline Ionizing radiation HHE & $\mathrm{kBq}$ U235 eq & 0.5809 & 0.5584 & 0.8296 \\
\hline Photochemical ozone formation & $\mathrm{kg} \mathrm{NMVOC} \mathrm{eq}$ & 0.0276 & 0.0275 & 0.0273 \\
\hline Acidification & molc H+ eq & 0.0701 & 0.0697 & 0.0748 \\
\hline Terrestrial eutrophication & molc N eq & 0.1472 & 0.1469 & 0.1444 \\
\hline Freshwater eutrophication & $\mathrm{kg} \mathrm{P} \mathrm{eq}$ & 0.0010 & 0.0010 & 0.0010 \\
\hline Freshwater ecotoxicity & CTUe & 19.7498 & 20.6068 & 20.0737 \\
\hline Water resource depletion & $\mathrm{m} 3$ water eq & 0.6496 & 0.6556 & 0.3854 \\
\hline Mineral, fossil \& res. depletion & $\mathrm{kg} \mathrm{Sb} \mathrm{eq}$ & 0.0002 & 0.0002 & 0.0002 \\
\hline Land use & $\mathrm{kg} \mathrm{C} \mathrm{deficit}$ & 41.7968 & 41.6876 & 41.2143 \\
\hline
\end{tabular}

Source: Own creation based on SimaPro simulations (Simulation data: February 2019)

Table 8. Cumulative impact contribution of each life cycle phase

\begin{tabular}{|c|c|c|c|c|c|c|}
\hline & & & Life & Cycle Phases & & \\
\hline & Impact Category & $\begin{array}{c}\text { Raw material } \\
\text { acquisition }\end{array}$ & $\begin{array}{c}\text { Fabric } \\
\text { production }\end{array}$ & $\begin{array}{c}\text { Garment } \\
\text { Manufacturing }\end{array}$ & $\begin{array}{c}\text { Consumer } \\
\text { Use }\end{array}$ & $\begin{array}{l}\text { End of } \\
\text { the life }\end{array}$ \\
\hline 1 & $\begin{array}{ll}\begin{array}{l}\text { Water } \\
\text { depletion }\end{array} & \text { resource } \\
\end{array}$ & 95.5 & $93.0^{*}$ & $92.9^{*}$ & $92.9^{*}$ & $\overline{100}$ \\
\hline 2 & $\begin{array}{l}\text { Human toxicity - cancer } \\
\text { effects }\end{array}$ & 31.7 & 83.0 & 84.0 & 85.0 & 100 \\
\hline 3 & $\begin{array}{lll}\begin{array}{l}\text { Ecotoxicity } \\
\text { water }\end{array} & - \text { fresh } \\
\end{array}$ & 82.2 & 93.1 & 93.3 & 93.9 & 100 \\
\hline 4 & $\begin{array}{l}\text { Human toxicity - non- } \\
\text { cancer effects }\end{array}$ & 26.6 & 85.9 & 86.3 & 86.4 & 100 \\
\hline 5 & Ozone depletion & 0.31 & 99.6 & 99.6 & 99.7 & 100 \\
\hline 6 & $\begin{array}{l}\text { Ionizing radiation - } \\
\text { human health effects }\end{array}$ & 9.6 & 76.9 & 79.4 & 80.3 & 100 \\
\hline 7 & $\begin{array}{l}\text { Particulate matter/ } \\
\text { respiratory inorganics }\end{array}$ & 15.7 & 92.2 & 95.0 & 95.7 & 100 \\
\hline 8 & Climate change & -1.64 & 72.6 & 74.7 & 75.3 & 100 \\
\hline 9 & Acidification & 26.9 & 88.0 & 92.2 & 93.0 & 100 \\
\hline 10 & $\begin{array}{l}\text { Mineral fossil and } \\
\text { resource depletion }\end{array}$ & 22.2 & 87.4 & 87.6 & 87.7 & 100 \\
\hline 11 & $\begin{array}{l}\text { Terrestrial } \\
\text { eutrophication }\end{array}$ & 45.8 & 88.5 & 92.4 & 93.4 & 100 \\
\hline 12 & $\begin{array}{l}\text { Photochemical ozone } \\
\text { formation }\end{array}$ & 20.5 & 83.3 & 88.8 & 90.6 & 100 \\
\hline 13 & $\begin{array}{l}\text { Freshwater } \\
\text { eutrophication }\end{array}$ & 27.2 & 70.5 & 71.6 & 71.6 & 100 \\
\hline 14 & Land Use & 92.0 & 97.9 & 98.0 & 98.2 & 100 \\
\hline
\end{tabular}

Note: Values expressed in percentages. Numbers in bold represent the life-cycle phase that reach $50 \%$ of cumulative impact contribution to any impact category.

*The decrease with respect to the previous life-cycle phase could be accounted for in this specific case by the use of a renewable electric energy source which has resulted in a reduction in this impact category.

Source: Own creation based on SimaPro simulation using "Scenario 2" (Simulation data: February 2019) 
Table 9. Relationship between environmental hotspot and environmental aspects managed and

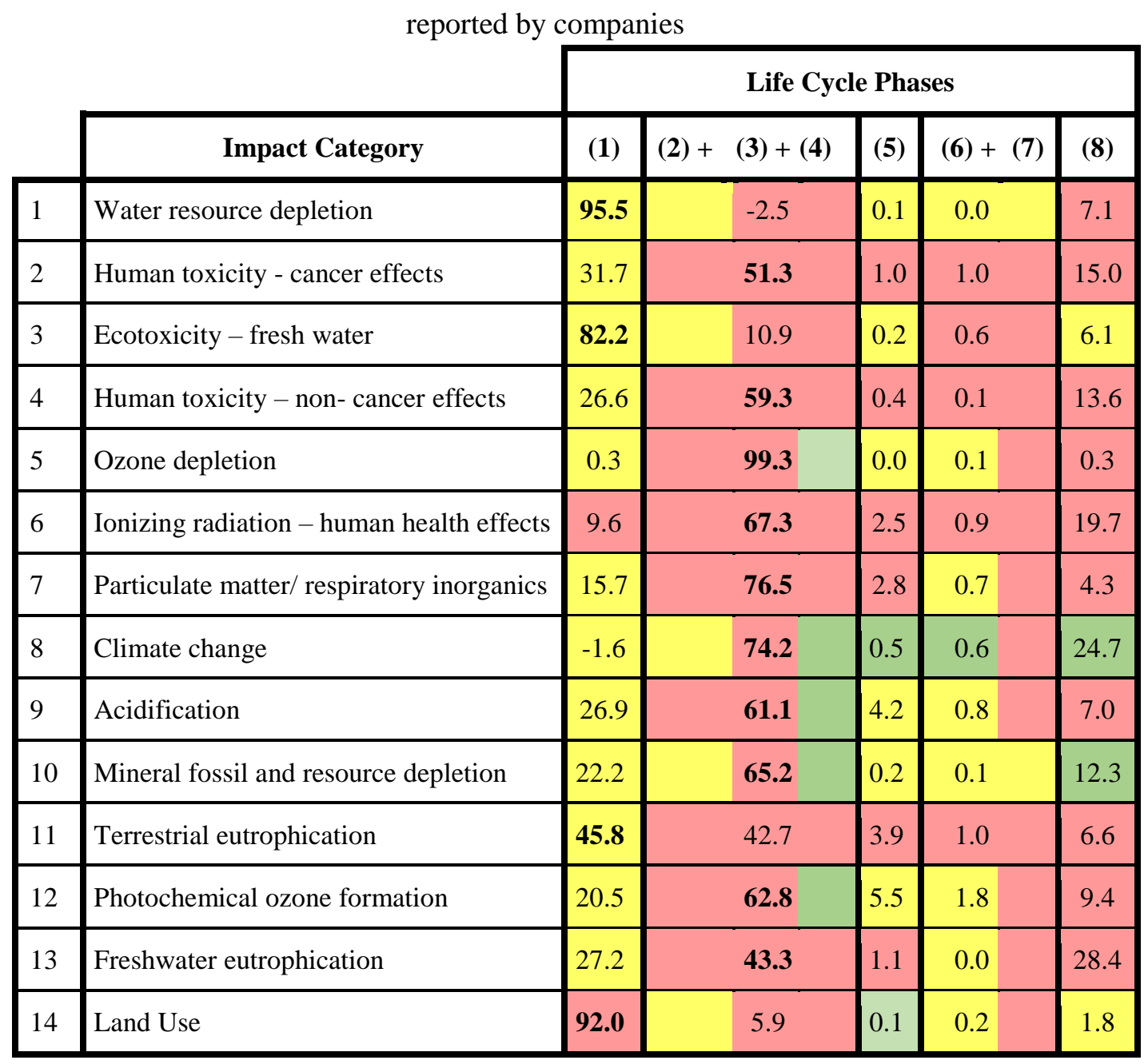
(1) Raw material acquisition
(2) Carding and spinning + (3) Dyeing, washing and rising + (4) Transportation
(5) Garment manufacturing
(6) Transportation and Distribution $+(7)$ Consumer use
(8) Disposal/reuse

$100 \%$ of the companies in the sample define at least one indicator linked with the impact category.

None of the companies define an indicator linked with the impact category.

Otherwise.

Values expressed in percentages. Numbers in bold represent the life-cycle phase that presents the largest contribution to the impact of any category.

Source: Own creation based on SimaPro simulation using "Scenario 2" (Simulation data: February 2019) 